\title{
A coupled terrestrial and aquatic biogeophysical model of the Upper Merrimack River watershed, New Hampshire, to inform ecosystem services evaluation and management under climate and land-cover change
}

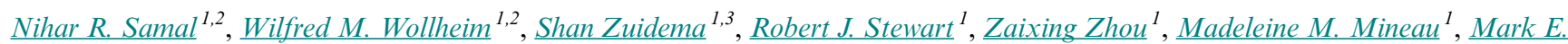

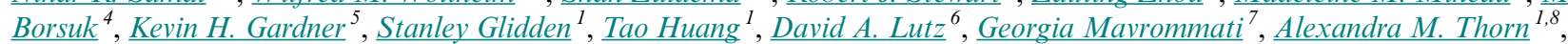 \\ Cameron P. Wake ${ }^{1,3}$ and Matthew Huber ${ }^{1,9}$
}

\begin{abstract}
Accurate quantification of ecosystem services (ES) at regional scales is increasingly important for making informed decisions in the face of environmental change. We linked terrestrial and aquatic ecosystem process models to simulate the spatial and temporal distribution of hydrological and water quality characteristics related to ecosystem services. The linked model integrates two existing models (a forest ecosystem model and a river network model) to establish consistent responses to changing drivers across climate, terrestrial, and aquatic domains. The linked model is spatially distributed, accounts for terrestrial-aquatic and upstreamdownstream linkages, and operates on a daily time-step, all characteristics needed to understand regional responses. The model was applied to the diverse landscapes of the Upper Merrimack River watershed, New Hampshire, USA. Potential changes in future environmental functions were evaluated using statistically downscaled global climate model simulations (both a high and low emission scenario) coupled with scenarios of changing land cover (centralized vs. dispersed land development) for the time period of 1980-2099. Projections of climate, land cover, and water quality were translated into a suite of environmental indicators that represent conditions relevant to important ecosystem services and were designed to be readily understood by the public. Model projections show that climate will have a greater influence on future aquatic ecosystem services (flooding, drinking water, fish habitat, and nitrogen export) than plausible changes in land cover. Minimal changes in aquatic environmental indicators are predicted through 2050, after which the high emissions scenarios show intensifying impacts. The spatially distributed modeling approach indicates that heavily populated portions of the watershed will show the strongest responses. Management of land cover could attenuate some of the changes associated with climate change and should be considered in future planning for the region.
\end{abstract}

Key Words: climate; coupled model; ecosystem services; indicators land cover; scenarios

\section{INTRODUCTION}

Understanding changes in ecosystem services at regional scales is increasingly important for environmental scientists, managers, planners, and decision makers as climate and land-use change continue (de Groot et al. 2010). Management decisions require an improved understanding of the drivers and processes that influence ecosystem services. Change in major environmental drivers, such as climate and land cover, typically result in large changes in ecosystem service supply (Schroeter et al. 2005). These changes are interactive and complex across space and time (Chen et al. 2013), requiring the development of appropriate methods to elucidate functional tradeoffs between management strategies. In order for stakeholders and citizens to be able to assess the value of the ecosystem services being provided, they need them to be expressed in terms of indicators that clearly relate to environmental condition (Nelson et al. 2009, Carpenter et al. 2015, Qiu and Turner 2015). Indicators of ecosystem services should be quantifiable, scalable (Bagstad et al. 2013a, Carpenter et al. 2015), explicit in time and space, and sensitive to land-cover or management change (Burkhard et al. 2012, van Oudenhoven et al. 2012). Moreover, the appropriate indicator is dependent on the method by which the ecosystem service is being valued (de Groot et al. 2010). Commonly used indicators that are easily monetizable may be incomplete for more comprehensive sociocultural preference valuations (Mavrommati et al. 2017).

Aquatic ecosystems are strongly influenced by terrestrial environments in their watersheds. Indicators of environmental condition related to climate and land cover can be generated at regional scales from existing meteorological observations, downscaled projections, land-cover atlases, or land-cover change scenarios (Queiroz et al. 2015). However, these simple evaluations are difficult in freshwater systems because responses depend on terrestrial and climate conditions integrated over entire watersheds and that vary over time. Terrestrial environments, interacting with climate, determine flow, temperature, and nutrient regimes in regional drainage networks (Poff et al. 1997). Hydrology is the overriding control of many aquatic ecosystem services (Brauman et al. 2007) influencing water availability, instream habitats, water temperatures, and nutrient fluxes. Aquatic ecosystems are further influenced by internal processes such as temperature re-equilibration and nutrient removal as water flows from upstream to downstream (Hale et al. 2014). To understand changes in ecosystem services, linked terrestrial and aquatic ecosystem models are needed to capture the processes defining responses to changing land cover and climate, partition

${ }^{1}$ Earth Systems Research Center, Institute for the Study of Earth, Oceans, and Space, University of New Hampshire, ${ }^{2}$ Department of Natural Resources and the Environment, University of New Hampshire, ${ }^{3}$ Department of Earth Sciences, University of New Hampshire, ${ }^{4}$ Department of Civil and Environmental Engineering, Duke University, ${ }^{5}$ Department of Civil and Environmental Engineering, University of New Hampshire, ${ }^{6}$ Environmental Studies Program, Dartmouth College, ${ }^{7}$ School for the Environment, University of Massachusetts Boston, ${ }^{8}$ Gerald J. and Dorothy R. Friedman School for Nutrition Science and Policy, Tufts University, ${ }^{9}$ Earth, Atmospheric, and Planetary Sciences Department, Purdue University 
the influence of each, and permit estimation of responses beyond previously observed ranges.

A variety of spatially explicit models or tools have been used for watershed-scale studies of environmental indicators and ecosystem services. Examples include Artificial Intelligence for Ecosystem Services (ARIES) (Villa et al. 2009), Multiscale Integrated Models of Ecosystem Services (MIMES) (Boumans et al. 2015), and Integrated Valuation of Ecosystem Services and Tradeoffs (InVEST) (Tallis and Polasky 2009, Bagstad et al. 2013b, Tallis et al. 2013). These models do not capture seasonal or subseasonal climate variability, which is projected to change regionally (Wood et al. 2002, Hayhoe et al. 2007, Horton et al. 2014) and is important for capturing watershed functions related to flood attenuation, water provisioning, river temperature regulation, and other ecosystem services (Vigerstol and Aukema 2011). To fully account for changes in ecosystem function associated with altered precipitation, temperature, and land-use and land-cover patterns, process-based models that incorporate key space- and time-varying hydrological and ecological processes are critical (Bagstad et al. 2013b).

Several processed-based terrestrial and/or aquatic biogeophysical models have recently been used for ecosystem service valuation (Logsdon and Chaubey 2012a, Bagstad et al. 2013a, Carpenter et al. 2015). The Variable Infiltration Capacity (VIC) model is a large-scale, semidistributed hydrological model (Liang et al. 1994) that simulated provisioning hydrological ecosystem services (Vigerstol and Aukema 2011) and flood regulation (Lee et al. 2015). The Soil Water Assessment Tool (SWAT), a process-based, spatially distributed hydrological and water quality model (Notter et al. 2012) was used to evaluate aquatic environmental variables, including water yield (Karabulut et al. 2015) and water quality (Logsdon and Chaubey 2012b). To compute dynamic ecosystem services in the agricultural Yahara watershed, a linked terrestrialaquatic model used a process-based agroecosystem model (AgroIBIS) (Soylu et al. 2014, Carpenter et al. 2015), a terrestrial hydrology model (THMB) (Coe 2000), a three-dimensional groundwater flow model (MODFLOW) (Harbaugh 2005), and a hydrological routing model (HYDRA), which lacked instream biogeochemistry (Coe 2000). There are a few robust examples of coupled human and biogeophysical models that have quantified ecosystem services at global (Boumans et al. 2002) and watershed (Costanza et al. 2002) scales. The Global Unified Metamodel of the Biosphere (GUMBO) simplifies several existing dynamic global models of both natural and social systems at an intermediate level of complexity and annual time-step (Boumans et al. 2002). The Patuxent Landscape Model (PLM; Costanza et al. 2002) is a spatially explicit process-based model that addresses the effects of both the magnitude and spatial patterns of human settlements and agricultural practices on hydrology, plant productivity, and nutrient cycling in the landscape, also at an annual time-step. Finally, valuation of ecosystem service information for land-use decisions has been estimated directly through an agent-based modeling framework (Heckbert et al. 2010, 2014, Groeneveld et al. 2017).

Our study contributes to the evolution of ecosystem service models by emphasizing shorter-term temporal dynamics in a spatially distributed and process-based framework that links terrestrial and aquatic function. This framework provides a new perspective for understanding the impacts that climate and landcover and land-use change have on terrestrial and aquatic resources.

We present an approach that links time-varying (daily time-step) terrestrial and aquatic ecosystem models at regional scales and apply this model into the future using scenarios of climate and land cover to project changes in ecosystem services. First, we describe an indicator framework that succinctly represents a comprehensive suite of environmental conditions relevant to important ecosystem services. Second, we describe the linkage and validation of the terrestrial and aquatic ecosystem models to simulate aquatic indicators through the 21 st century. We integrated the Photosynthetic Evapotranspiration-Carbon and Nitrogen (PnET-CN) forest ecosystem model (Ollinger et al. 2002, 2008, Aber et al. 2005) and the Framework for the Aquatic Modeling of the Earth System (FrAMES) aquatic ecosystem model (Wollheim et al. 2008a, $b$, Wisser et al. 2010, Stewart et al. 2011, 2013, Mineau et al. 2015; Zuidema, Wollheim, Mineau, et al., unpublished manuscript). These models integrate the dynamics of terrestrial and aquatic processes and linkages at daily timesteps, making them ideal for studying aquatic ecosystem responses in forest-dominated watersheds. In coordination with a separate effort described elsewhere in this special issue (Mavrommati et al. 2017) to assess the value of ecosystem services provided by the Upper Merrimack River watershed (UMRW) of New Hampshire, we contrast two extremes of projected futures in climate and land-cover change. The outcome suggests that climate change influences most indicators of environmental condition in the UMRW more than changes in land cover, although land cover has important interactive capacity to dampen or exacerbate the effects of the changing supply of ecosystem services in the future.

\section{METHODS}

The central goal of this study was to develop estimates of ecosystem function critical to current and future watershed residents of the UMRW. We present a description and rationale for studying this watershed and the development of environmental indicators relevant to ecosystem services of local residents. We next describe the integrated terrestrial-aquatic model that projects aquatic environmental indicators, including scenarios, parameterizations, and data sets needed to project aquatic indicators to 2100 . Finally, to understand how aquatic and terrestrial processes control the projected environmental conditions, we evaluate model sensitivity to a suite of climate and land-cover change (Thorn et al. 2017).

\section{Upper Merrimack River watershed}

The UMRW is located in south-central New Hampshire, USA. The UMRW comprises $8,000 \mathrm{~km}^{2}$ of New Hampshire and drains through a point just south of the city of Manchester, New Hampshire (Latitude: +43.6575, Longitude: -71.5005; Fig. 1). The watershed is currently home to 410,000 people, with ongoing population growth and land-cover change through extensive residential development, and is also an important tourist destination. Annual precipitation currently averages $1,100 \mathrm{~mm}$ $\mathrm{yr}^{-1}$ and is evenly distributed throughout the year. Mean annual temperature is currently $8.2^{\circ} \mathrm{C}$, with mean annual minimums and maximums of $-8.3^{\circ} \mathrm{C}$ and $22.5^{\circ} \mathrm{C}$, respectively. Land cover consists of a mix of deciduous and evergreen forest (82\%), urban $(4.2 \%)$, 
agriculture $(3.8 \%)$, wetland $(5.9 \%)$, and open water $(4.2 \%)$. As the dominant land cover, forests are a critical influence on the aquatic environment, including water supply, water quality, and aquatic habitat. The watershed sits at the boundary between strong and weak winters, and is expected to transition to greater and more variable precipitation and warmer temperatures in coming decades (Hayhoe et al. 2007, Burakowski et al. 2008, Wake et al. 2014). The area is also experiencing rapid population growth and ongoing residential development, which is expected to continue into the future (U.S. Environmental Protection Agency (USEPA) 2010). The Merrimack watershed is ranked in the top five watersheds nationally in terms of projected changes in water quality due to increase housing density on private forest lands and ranks at the top of the list in terms of private forest land projected to experience increased housing density in the USA (Stein et al. 2009). These changes are leading to increased water use, nitrogen $(\mathrm{N})$ fluxes, chloride concentrations, and other changes. Thus, this watershed is an ideal location to focus efforts in understanding ecosystem service change.

Fig. 1. Merrimack and Piscataqua River networks and watershed boundaries showing distribution of land cover and validation data stations.

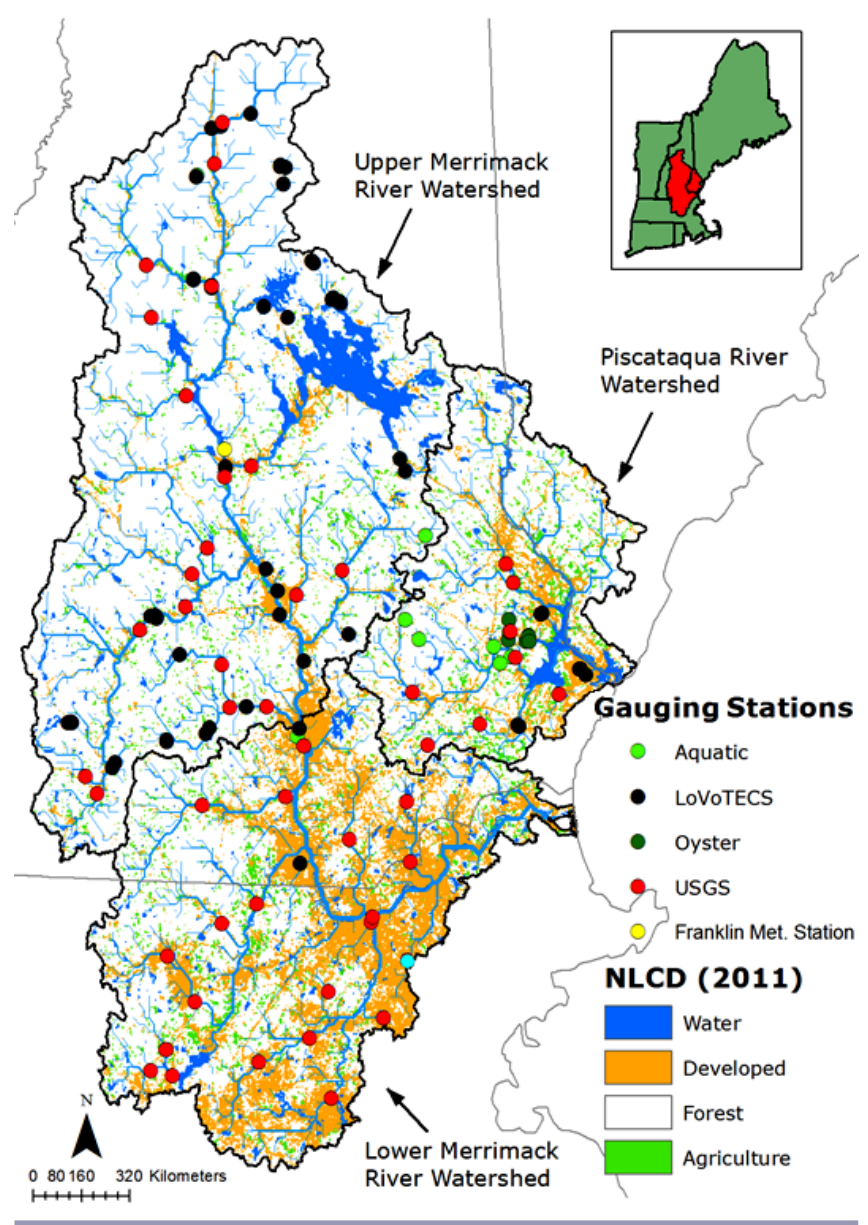

\section{Environmental indicators}

Identifying clear and tangible environmental indicators is a necessary step to communicate the response of complicated human-environmental systems to change (Müller and Burkhard 2012) and to track the performance of environmental programs, regulations, and agencies (Boyd 2004). A multidisciplinary group consisting of ecologists, hydrologists, engineers, economists, and decision scientists developed a set of potential environmental indicators important to the study region. We used an iterative and collaborative process to distill a set of climate, terrestrial, and aquatic ecosystem variables to environmental indicators. Changes in these indicators in response to different climate and land-cover scenarios were then assigned a relative value by participants in a set of multicriteria decision workshops described elsewhere (Mavrommati et al. 2017, Murphy et al. 2017).

The indicators represented multidecadal average conditions in the UMRW for the present (1980-2005) and projected for the end of the 21 st century (2070-2099). Candidate indicators had relevance to climate, land, and water domains. Terrestrial indicators were based on land-cover scenarios (Thorn et al. 2017) and the Northern Research Station Climate Change Atlas (Iverson et al. 2008). Climate indicators were based the Geophysical Fluid Dynamics Laboratory (GFDL) CM2.1 global climate model (GCM) simulations using the SRES A1Fi (higher) and B1 (lower) emissions scenarios (Nakicenvoic and Swart 2000) that were statistically downscaled using the asynchronous regional regression model (Stoner et al. 2012, Wake et al. 2014). The downscaled GFDL simulations were used as they provide a reasonable representation of climate across the northeast USA (Hayhoe et al. 2007). Given the multiple land-cover and emissions scenarios used in this study, we only had the capacity to use output from one GCM. We used downscaled global climate model simulations for the Franklin, New Hampshire meteorological station, centrally located within the study domain. Water-related environmental factors were derived at the watershed scale using the coupled terrestrial-aquatic process-based model to predict ecosystem function consistent with the land-cover and climate scenarios. Generating indicators based on model simulations at daily time-steps permits the clear definition from key variables such as concentrations, temperature, or flow volumes compared with key thresholds relevant at the scale of days. Translation of environmental indicators to indicators of ecosystem services and valuation of these services is discussed later in the special issue (Mavrommati et al. 2017).

\section{Coupling of terrestrial and aquatic models}

We coupled the existing forest (PnET-CN) and aquatic (FrAMES) models to simulate hydrological and water quality characteristics related to ecosystem services, consistent with forest responses to climate, at regional scales. The detailed description of the individual PnET-CN and FrAMES models are presented in Appendix 1, sections 1.2 and 1.3. The PnET-CN model is widely used to simulate forest water, carbon (C), and $\mathrm{N}$ dynamics (Aber et al. 2005, Ollinger et al. 2008). The FrAMES model (Wollheim et al. 2008a, $b$, Wisser et al. 2010, Stewart et al. 2011, 2013) is a spatially distributed gridded river network model that has been applied extensively at various spatial scales ranging from watershed to global domain for simulating $\mathrm{N}$ dynamics in rivers (Wollheim et al. 2008a, $b$, Stewart et al. 2011), runoff/discharge dynamics (Vörösmarty et al. 1998, Wisser et al. 2010), river water temperature (Stewart et al. 2013), and chloride concentration (Zuidema, Wollheim, Mineau, et al., unpublished manuscript). Typically, FrAMES has a land-surface hydrology component that operates independently of forest dynamics. Here, we substitute 
PnET-CN predictions of runoff and $\mathrm{N}$ to load material from forests to river networks.

The PnET-CN model accounts for the influence of photosynthesis on evapotranspiration and nutrient uptake, forest age, and plant physiological responses (stomatal conductance) to changing $\mathrm{CO}_{2}$ (Ollinger et al. 2008). Together, these factors control $\mathrm{C}$ sequestration, nutrient export, and runoff generation immediately relevant to several ecosystem services. In the coupled model (Fig. 2), PnET-CN calculates daily runoff and dissolved inorganic nitrogen (DIN) flux from forest rooting zones. These outputs are then partitioned into shallow groundwater or surface (quick flow) flow paths, with different characteristic travel times. In urban regions, precipitation and snowmelt on hydrologically connected impervious areas run directly to the stream network, with the remainder infiltrating to lawn areas. Chloride, a potential stressor of aquatic biota, from snowmelt on the road-salt-treated fraction of impervious areas is transported conservatively following the soil and groundwater flow paths (Zuidema, Wollheim, Mineau, et al., unpublished manuscript). To link with the aquatic network, we also incorporated the role of terrestrial flow paths and riparian zones in regulating DIN loads. The PnET$\mathrm{CN}$ model predicts leaching from the forest rooting zone. To account for retention along terrestrial-riparian flow paths, we applied a constant retention factor of $70 \%$ to all leachate, consistent with reactivity of riparian zones (Green et al. 2009) or buffers that average about $25 \mathrm{~m}$ (Mayer et al. 2005). We account for DIN loading from urban and agricultural areas using an empirical relationship between DIN, land use, and flow found in other New England watersheds (Wollheim et al. 2008a, $b$, Stewart et al. 2011, Mineau et al. 2015). Water temperature in terrestrial runoff is modeled as described in Stewart et al. (2013). Water temperature and DIN inputs from land are further modified by instream processes as water flow through the river network.

Fig. 2. Conceptual diagram of the terrestrial and aquatic ecosystem model coupling and factors influencing environmental indicators.

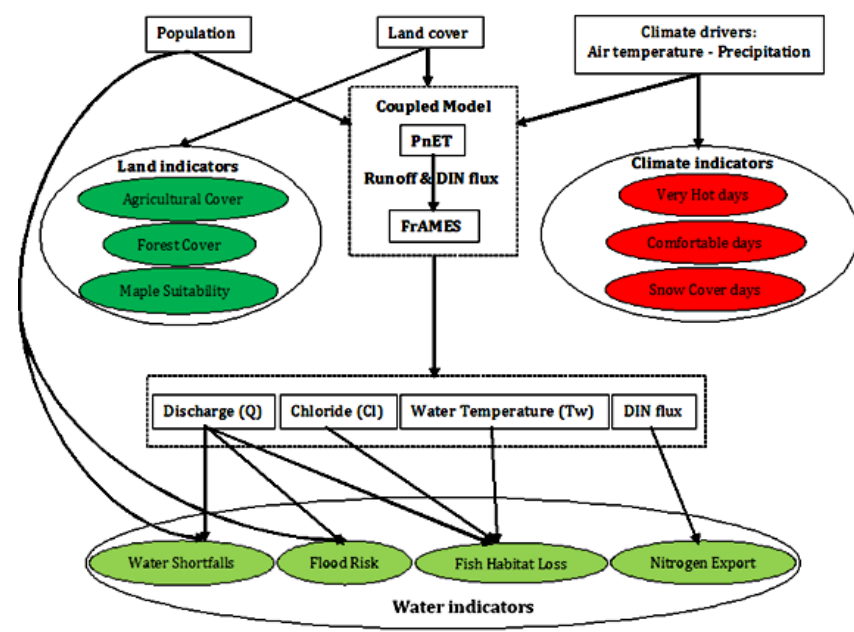

FrAMES routes water, DIN, water temperature, and chloride originating from forests and urban and agricultural land through the river network, accounting for additional point sources of contaminants, such as $\mathrm{N}$ in waste water treatment plant (WWTP) effluent and thermal loads from power plant cooling water processes (Stewart et al. 2013, Miara and Vörösmarty 2013). It also accounts for instream transformations during routing, such as dilution, denitrification (Wollheim et al. 2008b, Stewart et al. 2011), and instream temperature re-equilibration (Stewart et al. 2013). River discharge, solute masses, and thermal fluxes are propagated through the gridded river network using a linear reservoir routing scheme. Thus, PnET-FrAMES accounts for terrestrial-aquatic and upstream-downstream linkages to provide a mutually consistent climate, land, and water response in future scenarios. The model was first applied to historical conditions (2000-2015) to test against field observations using downscaled reanalysis meteorological observations and current land cover. Meteorological forcing for future scenarios used statistically downscaled climate data from Hayhoe et al. (2007), and land cover from Thorn et al. (2017). A detailed summary of the model input data for contemporary and future scenarios is described in Appendix 2.

\section{Model parameterization}

Model parameters were specified a priori. For future scenarios, parameters that are responsive to human management were altered to be consistent with each scenario narrative (Table 1). Key parameters include the fraction of hydrological connected imperviousness (affecting flow regime, total runoff), road salt application rates (affecting water quality), suburban and agricultural DIN nonpoint loading, and WWTP DIN point loading (affecting $\mathrm{N}$ exports). We are using the term "land cover" in describing future changes to the landscape. Management decisions that are consistent with the land-cover narratives (e.g., stormwater and wastewater infrastructure) are included in the parameterization of FrAMES-PnET. Specific parameterizations and how they vary by scenario are provided in Appendix 3.

\section{Model testing with observed data}

To validate the linked suite of models, we compared model simulations with data from headwater and downstream gauge locations to determine how well the spatial and temporal distribution of inputs, dilution, and processing are simulated. Observed data represented aquatic conditions at a total of 106 stations located throughout the Merrimack River and the neighboring Piscataqua River watersheds (Fig. 1). The latter is included in contemporary simulations to increase the pool of observations. Mean daily discharge data (1979-2013) were available from the U.S. Geological Survey (USGS) $(n=41$ stations). Additional observed variables, including water temperature and concentrations of DIN and chloride came from two networks of in situ sensors: the High Intensity Aquatic Network (HIAN) $(n=12$ stations $)$ and Lotic Volunteer Temperature Electrical Conductivity and Stage (LoVoTECS) network ( $n=53$ stations). Data from the HIAN (Mulukutla et al. 2015) and LoVoTECS network (LoVoTECS 2012) are available through the Data Discovery Center (http://ddc.unh.edu) over the timeframe of 2012-2014 and are also reported in Contosta et al. (2017). We compared predictions to observations of both mean annual and mean summer conditions using contemporary land-cover and climate drivers. We calculated model prediction errors (MPE) and root mean square errors (RMSE) for temperature, runoff, and nitrate and chloride concentrations. We compared predictions in headwater streams 
Table 1. Statistical details of different land-cover scenarios used in this study (based on Thorn et al. 2017).

\begin{tabular}{|c|c|c|c|c|c|c|}
\hline \multicolumn{2}{|r|}{ Scenario } & \multicolumn{3}{|c|}{ Cover in $2100(\%)$} & \multirow[t]{2}{*}{ Population } & \multirow[t]{2}{*}{ Management } \\
\hline Short Name & Long Name & Forest & $\mathrm{Ag}$ & Dev & & \\
\hline Constant Land Cover & Constant Land Cover & 80 & 4.2 & 4.5 & 410,000 & Maintain present-day land cover \\
\hline Small Community Food & $\begin{array}{l}\text { Small population Community } \\
\text { Amenities with Prioritization of } \\
\text { Local Food }\end{array}$ & 64 & 20 & 4.5 & 380,000 & $\begin{array}{l}\text { Centralized municipalities, low-impact } \\
\text { design (stormwater), low-impact } \\
\text { agricultural }\end{array}$ \\
\hline $\begin{array}{l}\text { Large Community } \\
\text { Wildlands }\end{array}$ & $\begin{array}{l}\text { Large population Community } \\
\text { Amenities with Prioritization of } \\
\text { Wildlands }\end{array}$ & 80 & 4.6 & 4.5 & 975,000 & $\begin{array}{l}\text { Centralized municipalities, low-impact } \\
\text { design (stormwater), low-impact } \\
\text { agriculture }\end{array}$ \\
\hline Backyard & $\begin{array}{l}\text { Large population Backyard } \\
\text { Amenities }\end{array}$ & 60 & 2.6 & 26 & 975,000 & Dispersed and decentralized \\
\hline
\end{tabular}

(to test predictions of inputs from land) and along the Merrimack River main stem to test the regionalization and aquatic process component of the model.

\section{RESULTS AND DISCUSSION}

\section{Choice of environmental indicators}

The iterative and collaborative process of environmental indicator selection identified ten indicators, from an initial set of 43 (Table A2.1), to represent a comprehensive suite of environmental conditions for the UMRW. The experts group used the criteria that indicators should hold perceived relevance to the general public, should equitably represent the three domains, and should be constrained by existing modeling capability. The selected indicators represented three indicators for each of land and climate domains, and four indicators for the water domain. The indicators are defined in Table 2 and explained in detail in the supplementary material (Appendix 2). The ten selected indicators are similar to several included in comprehensive lists generated previously (de Groot et al. 2010, Burkhard et al. 2012). However, our final indicators differed from previous lists to be more relevant to local residents. For instance, we used total forest cover as a percentage of the watershed instead of wood biomass stock in units of mass per area (de Groot e al. 2010) based on lack of relevance of wood biomass to the general public living in the watershed. The water indicators emphasized basin scale and subannual estimates of water conditions, requiring space- and time-varying aquatic modeling. The choice of indicators in representing specific ecosystem services is discussed more thoroughly elsewhere in this special issue (Mavrommati et al. 2017).

\section{Regional validation of the coupled model}

The component ecosystem models used in this analysis have been previously validated individually. The PnET-CN model was validated for water and nutrient balance, (Ollinger et al. 2002, 2008, Aber et al. 2005), whereas FrAMES was validated for river discharge using a simple water balance model (Vörösmarty et al. 1998, Wisser et al. 2010), water temperature (Stewart et al. 2013), chloride (Zuidema, Wollheim, Mineau, et al., unpublished manuscript), and riverine DIN (Wollheim et al. 2008a, $b$, Stewart et al. 2011). In this study, terrestrial vegetation processes in PnETFrAMES drive regional runoff, nutrient, chloride, and water temperature loading that is then routed through the network.

Regional predictions of water variables using PnET-FrAMES generally compared favorably to observations. Modeled annual runoff matches observations, with little bias indicated by a low median model percent error (MPE) of $4.4 \%(\mathrm{IQR}=-5.7-11.7 \%)$

Table 2. Definitions and units of selected environmental indicators. $(\mathrm{P}=$ Person, $\mathrm{d}=$ day, $\mathrm{yr}=$ year $)$

\begin{tabular}{|c|c|c|}
\hline $\begin{array}{l}\text { Selected } \\
\text { Indicators }\end{array}$ & Description & Units \\
\hline \multicolumn{3}{|l|}{ Land } \\
\hline $\begin{array}{l}\text { Agricultural } \\
\text { cover }\end{array}$ & $\begin{array}{l}\text { Agricultural land available per } \\
\text { capita }\end{array}$ & Acre $\mathrm{P}^{-1}$ \\
\hline Forest Cover & Watershed in forest cover & $\%$ watershed \\
\hline Maple & Maple suitable & $\%$ forest cover \\
\hline Suitability & & \\
\hline \multicolumn{3}{|l|}{ Climate } \\
\hline $\begin{array}{l}\text { Very Hot } \\
\text { Days }\end{array}$ & $\begin{array}{l}\text { Days maximum air temperature } \\
\text { exceeds } 32^{\circ} \mathrm{C}\end{array}$ & $\mathrm{d} \mathrm{yr}^{-1}$ \\
\hline Comfortable & Days maximum air temperature & $\mathrm{d} \mathrm{yr}^{-1}$ \\
\hline Days & between $21-32^{\circ} \mathrm{C}$ & \\
\hline Snow Cover & Days snowpack exceeds $150 \mathrm{~mm}$ (30 & $\mathrm{d} \mathrm{yr}^{-1}$ \\
\hline Days & SWE) & \\
\hline \multicolumn{3}{|l|}{ Water } \\
\hline Water & Population duration of water & $\mathrm{Pd} \mathrm{yr}^{-1}$ \\
\hline Shortfalls & supply stress & \\
\hline Flood Risk & $\begin{array}{l}\text { Population duration of potential } \\
\text { flood impact }\end{array}$ & $\mathrm{Pd} \mathrm{yr}^{-1}$ \\
\hline $\begin{array}{l}\text { Fish Habitat } \\
\text { Loss }\end{array}$ & $\begin{array}{l}\text { River impaired by temperature, } \\
\text { chloride, or low flow }\end{array}$ & $\%$ \\
\hline Nitrogen & Nitrogen export exceeding estuary & $\mathrm{kg} \mathrm{N} \mathrm{yr}^{-1}$ \\
\hline & & \\
\hline
\end{tabular}

at gauging stations throughout the project domain (Fig. 3a). Simulated runoff was somewhat higher than observations during summer months (median MPE $=15.9 \%, \mathrm{IQR}=-2.5-24.7 \%)($ Fig. $3 b$ ). Thus, whereas water indicators based on flow (Table 2) are reasonably well predicted, the Fish Habitat Loss and Water Shortfalls indicators (which are triggered by low-flow conditions) are likely conservative estimates.

Modeled water temperature across gauging stations is low for mean annual temperature (median $\mathrm{MPE}=-17.5 \%, \mathrm{IQR}=-32.7-$ $-9.2 \%$ ) with little bias during summer (median MPE $=-2.3 \%$, $\mathrm{IQR}=-8.1-5.5 \%)($ Fig. $3 b)$. Because the model does well during summer when temperatures are high, the water temperature component of the Aquatic Habitat indicator, which is mostly driven by summer conditions, is robust. No differences in bias were seen across different river sizes. 
Fig. 3. Box plots of model percent error (MPE) across all sites $(\mathrm{MPE}=(\mathrm{P}-\mathrm{O}) / \mathrm{O} * 100)$ for aquatic variables during annual (a) and summer (b) time periods (RO: Runoff; DIN: Dissolved Inorganic Nitrogen, Temp: Water Temperature; where, $\mathrm{P}$ is the predicted values by the model and $\mathrm{O}$ is the observed values at different sampling sites).

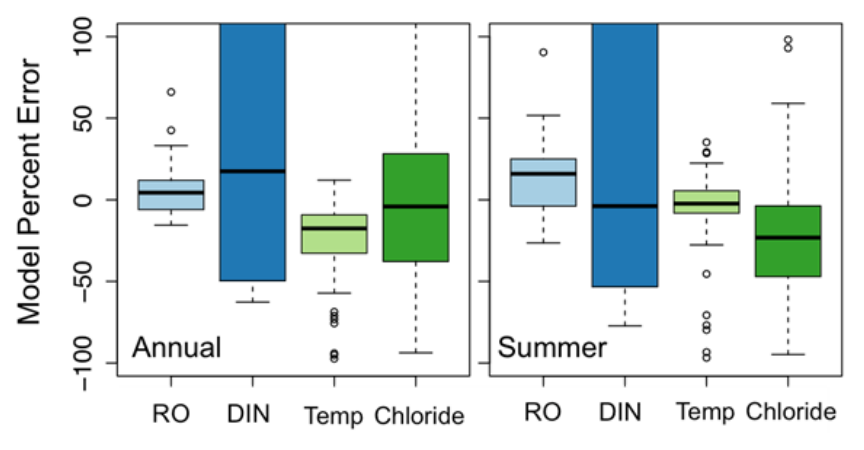

Modeled chloride concentrations are reasonable (median MPE $=-4.1 \%, \mathrm{IQR}=-37.8-28.2 \%)$ for annual and biased low for summer periods (median MPE $=-23.2 \%, \mathrm{IQR}=-47.0--3.8 \%$ for annual and summer, respectively) (Fig. 3). The low summer bias occurs because of a flashier response to summertime diluting rains than observations (Zuidema, Wollheim, Mineau, et al., unpublished manuscript). Rectifying this incompatibility is a subject of ongoing model improvement. Thus, the indicator that uses chloride (Fish Habitat Loss) is likely an underestimate, particularly during summers.

The PnET-FrAMES model captures the range of variability in mean annual DIN concentration loaded via nonpoint inputs in headwater streams of different land cover, which reflect catchment loading prior to river processing. Predicted DIN loading concentrations are higher than observed for forested catchments $(n=4)$, but show little bias for developed catchments $(n=6)$ (Fig. 3; Figs. A4.1c, A4.2c). The PnET-CN model is known to overestimate forest DIN (Zhou, Ollinger, Glidden, et. al., unpublished manuscript), and continues to do so here, even though we added a flow path/riparian retention term to PnET-FrAMES. As a result of high bias in forested sites, the percent errors for DIN in Fig. 3 are higher than other variables. However, absolute error at these sites is very low compared with the more developed sites (Figs. A4.1c, A4.2c). Overall bias is low in summer (median $\mathrm{MPE}=-3.9 \%, \mathrm{IQR}=-53.0-111.4 \%$ ) but high annually (median $\mathrm{MPE}=17.5 \%, \mathrm{IQR}=-41.8-186.4 \%)$. Dissolved inorganic $\mathrm{N}$ concentrations in headwater streams reflect loading because aquatic net removal has not had the opportunity to impact concentrations due to short surface water flow paths in small catchments (Wollheim et al. 2006). Observations along the river main stem (basin profile, Fig. A4.3a) indicate the model reasonably represents regional loading, dilution, and aquatic $\mathrm{N}$ removal throughout the river network (Fig. A4.4a).

\section{Regional framework for land, climate, and water indicators to 2100}

We characterized the suite of environmental responses to two land-cover and two climate scenarios selected for the valuation workshop (Mavrommati et al. 2017) meant to represent extremes of potential change in future conditions. We drove the model with the Backyard and Small Community Food Land-Cover scenarios (Table 1), with higher (A1Fi) and lower (B1) climate scenarios, respectively (Backyard/High emissions and Small Community Food/Low emissions).

Changes in the land indicators (Table 2; Agricultural Cover per person and Forest Cover) directly reflect the land-cover scenarios (Thorn et al. 2017) and have important direct ecosystem service implications. Briefly, in the Backyard scenario, watershed forest cover declines from $80 \%$ in 2010 to $60 \%$ in 2100 , to accommodate increased rural and suburban development (Fig. 4). In the Small Community Food/Low scenario, forest declines to $64 \%$ in 2100 , replaced by agricultural lands, primary for pasture and hay. By 2100 , population increases by $170 \%$ in the Backyard/High scenario and declines by $5 \%$ in the Small Community Food/Low scenario. The increase in agricultural land relative to population under the Small Community Food/Low scenario ( 1.0 acres per person in 2100 compared with 0.2 in 2010) increases the potential for per capita local food production compared with the contemporary period (Thorn et al. 2017). The Maple Presence indicator, which primarily represents the geographic distribution of suitable habitat for Acer saccharum (Iverson et al. 2008), declines from $49 \%$ of total forest cover in the present day to $27 \%$ and $31 \%$ in the Backyard/High emission and Small Community Food/Low emission scenarios, respectively. The declines result from shifts in climate associated with each land-cover scenario.

Fig. 4. Time series of land environmental indicators for Backyard Amenities / High Emissions and Small Community Amenities / Low Emission scenarios through 2100 for (a) Agricultural Cover (acres/person), (b) Forest Cover (proportion), and (c) Maple Suitability (\% forest cover).

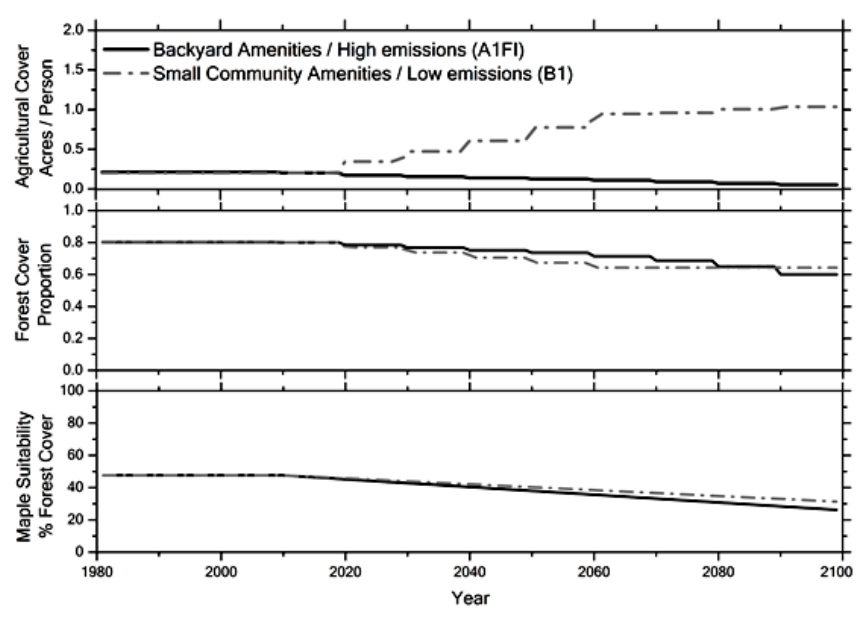

Projected changes in climate indicators in the UMRW are strongly determined by emission scenario. Present-day climate trends (Hodgkins and Dudley 2006, Hayhoe et al. 2007, Burakowski et al. 2008) continue through 2050 regardless of emission scenario (Fig. 5). Around 2050, the rate of warming is projected to increase rapidly under the Backyard/High emission scenario. With the high emission scenario, the hot days indicator increases sharply, averaging $>45 \mathrm{~d}$ above $32^{\circ} \mathrm{C}$ after 2075 (Fig. $5 a$ ). Under the lower 
emission scenario, the multiyear mean for hot days is considerably lower $\left(<17 \mathrm{~d} \mathrm{yr}^{-1}\right)$ (Fig. 5a). The Snow Days indicator declines under the higher emissions (averaging $18 \mathrm{~d} \mathrm{yr}^{-1}$ ) compared with contemporary mean $\left(60 \mathrm{~d} \mathrm{yr}^{-1}\right)$ and relative to the lower emissions scenario (47 $\mathrm{d} \mathrm{yr}^{-1}$ ) (Fig. 5c). Again, the change is accelerated after 2040. The Recreation Days indicator changes little under both the low and high emission scenarios (Fig. 5b). Minimal changes in recreation days results from loss of recreation days due to days becoming too hot during the summer being offset by additional days in the shoulder seasons (spring and fall) that were previously too cool falling in the recreation day range.

Fig. 5. Time series of climate environmental indicators for Backyard Amenities / High Emissions and Small Community Amenities / Low Emission scenarios through 2100 for (a) Very Hot days (days per year), (b) Comfortable days (days per year), and (c) Snow Cover days (days per year).

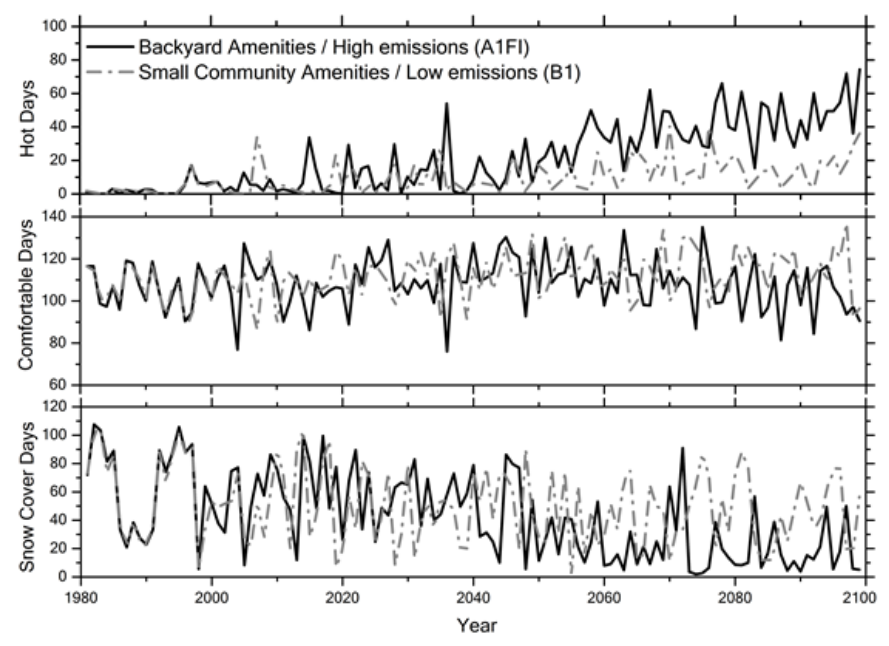

Environmental indicators in the water domain reflect the combined influence of projected climate and land-cover change, as well as terrestrial and aquatic processes. In general, all water indicators reflect increasing degradation of aquatic ecosystem services for the Backyard/High scenario, but remain relatively unchanged for the Small Community Food/Low scenario (Fig. 6). The Fish Habitat Loss indicator is projected to rise substantially in the Backyard/ High scenario to average about $40 \%$ of total stream and river length after 2075. Only slight increases, and fewer extreme events, occur under the Small Community Food/Low scenario. The Nitrogen Export indicator increases steadily over the 100-yr period for the Backyard/High scenario to 995 tons $\mathrm{N} \mathrm{yr}^{-1}$ up $3100 \%$ from current conditions. Under the Community/Low scenario, however, $\mathrm{N}$ export changes relatively less, increasing only $70 \%$ to an average of 52 tons $\mathrm{N} \mathrm{yr}^{-1}$. The steady increase in the Backyard/High scenario is due to elevated $\mathrm{N}$ loading associated with widespread land-cover change and increased population. The pattern in Community/Low occurs because in this scenario, agricultural management activities were assumed to reflect the greater concern for the environment (optimal fertilizer application rates, improved waste water treatment plant $\mathrm{N}$ removal), and because it reflects a lower human population (Table 1).
Fig. 6. Time-series of water environmental indicators for Backyard Amenities / High Emissions and Small Community Amenities / Low Emission scenarios through 2100 for (a) Fish Habitat Loss (\% river length impairment per year), (b) Nitrogen Export $\left(10^{6} \mathrm{x} \mathrm{kg} \mathrm{N}\right.$ per year), (c) Water Shortfalls (Million (M) person days per year), and (d) Flood Risk (Thousand (k) person days per year).

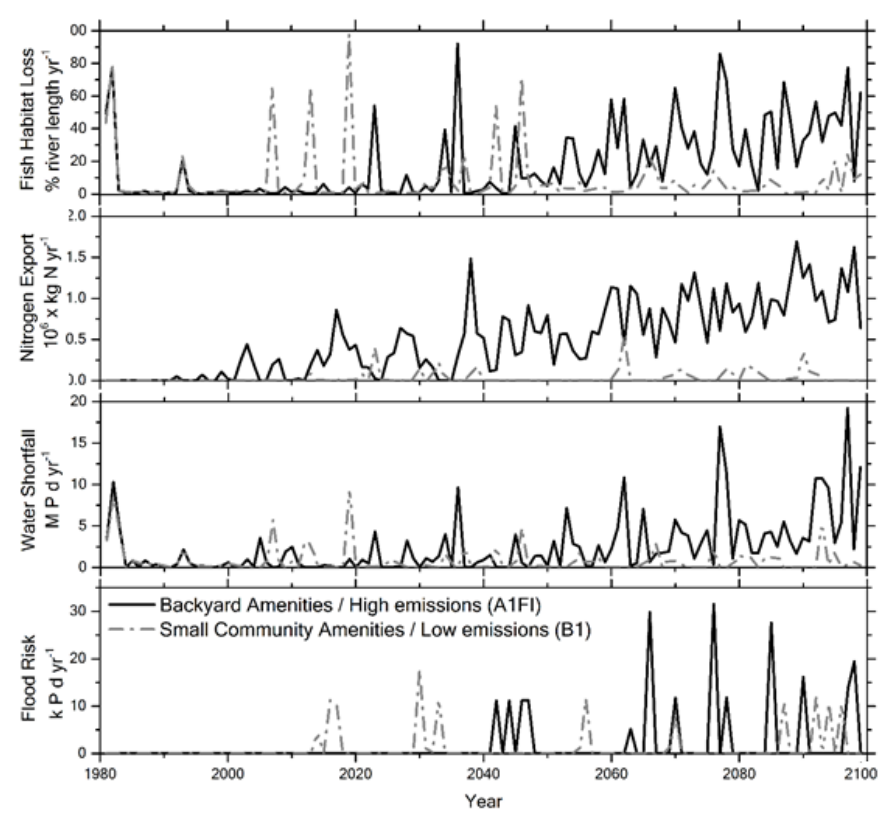

The Water Shortfall indicator increases in the future in Backyard/ High (averaging $6 \times 10^{6}$ person days [pd] $\mathrm{yr}^{-1}$ after the 2075) but remains unchanged in the Community/Low scenario. The Water Shortfall indicator increases in Backyard/High despite greater runoff that occurs due to increased precipitation (1320 compared with $1270 \mathrm{~mm} \mathrm{yr}^{-1}$ between the higher and lower emission scenarios, respectively) and lower forest evapotranspiration (ET) due to trees responding to increased atmospheric $\mathrm{CO}_{2}$ by increased water-use efficiency (Ollinger et al. 2002). The increase occurs because the greater population (in Backyard) reflects a greater demand that at times would be unmet.

The number of people at Flood Risk is expected to increase for both scenarios, although there is considerable interannual variability, which is expected because extreme flows only occur periodically. Total population affected after 2075 by extreme flows leading to Flood Risk is higher in the Backyard/High scenario $\left(1.2 \times 10^{5} \mathrm{pd}\right)$ than in Small Community Food/Low scenario $\left(4.4 \times 10^{4} \mathrm{pd}\right)$ because the former has a larger population to potentially be impacted, has higher flows on average, and has greater storm runoff due to increased imperviousness.

Overall, the suite of indicators suggests that relevant environmental conditions remain relatively stable until 2050 regardless of climate and land-cover scenario. Beginning in 2050, there is a potential for climate and water indicators to significantly deteriorate in the high emission scenario. The timing of the change in water indicators in Backyard/High suggests primarily a climate control, as climate changes also show rapid increases at this time (Fig. 5). 
Fig. 7. Distribution of water indicators between 2075-2100 for eight scenarios (four land use and two climate; Table 1) compared with contemporary range (1980-2005), including (a) Fish Habitat Loss $\left(\mathrm{km} \mathrm{d} \mathrm{yr}^{-1}\right)$, (b) Nitrogen Export $\left(\mathrm{kg} \mathrm{N} \mathrm{yr}^{-1}\right)$, (c) Water Shortfalls $\left(\mathrm{P} \mathrm{d} \mathrm{yr}^{-1}\right)$, and (d) total Flood Risk population-duration (P d). Boxes in panels (a)-(c) represent first to third quartiles of data with line defining median, whiskers extend to $1.5 \times \mathrm{IQR}$, outliers as circles beyond. Bars in (d) represent the cumulative total population potentially flood affected during the period. Highlighted columns depict scenarios included in workshop evaluation (Mavrommati et al. 2017) and focused on Figs. 4-6.
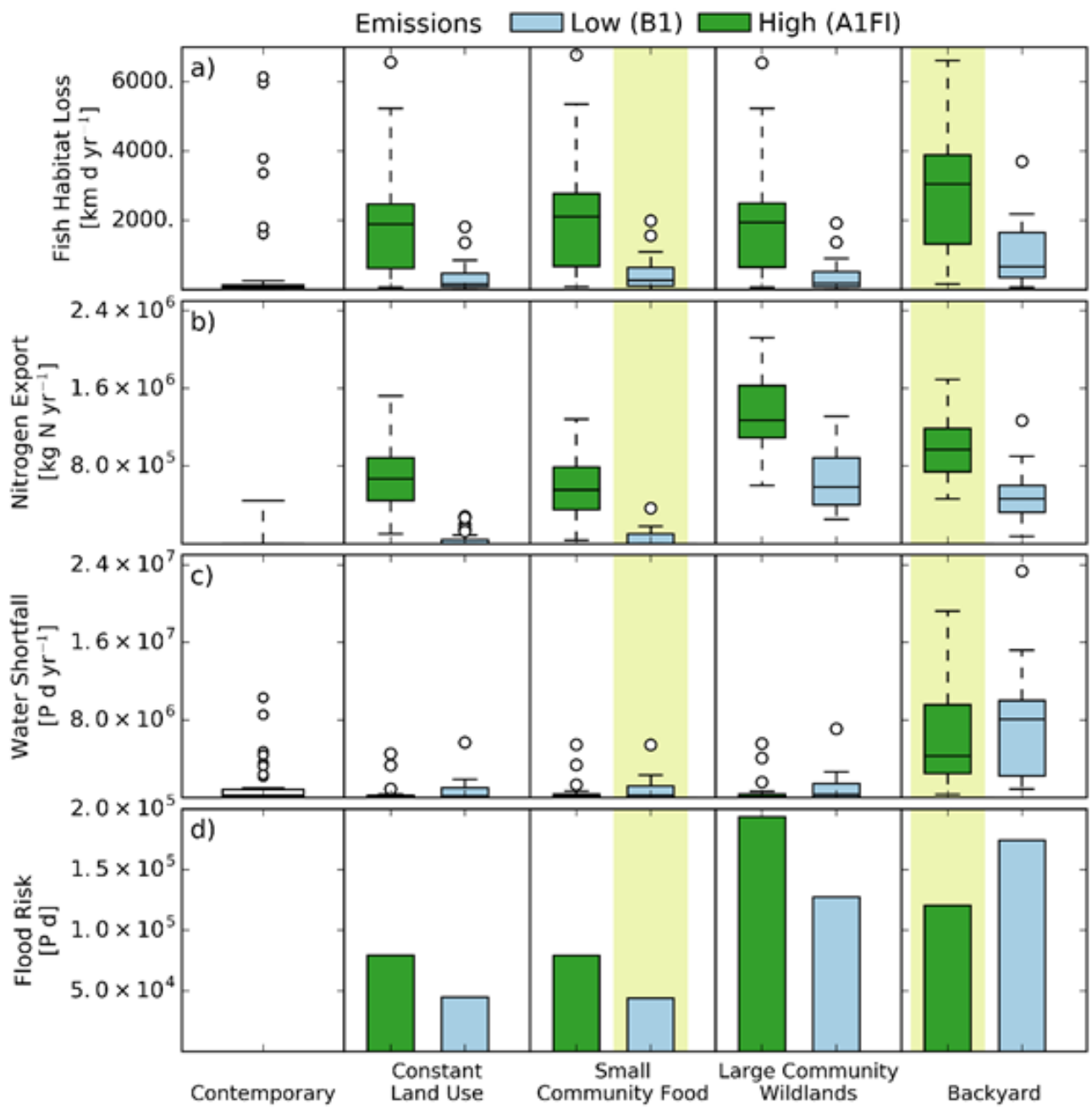

Using coupled models and multiple scenarios to partition influence of land cover and climate on water indicators

Climate drivers govern the hydrological and biogeochemical response of catchments, but these changes are mediated by land use and land cover through impacts of impervious surfaces, plant growth, evapotranspiration, and water residence time (Ollinger et al. 2002, Raymond and Saiers 2010, Pellerin et al. 2011, Goodridge and Melack 2012). The two scenarios described above convolve both signals (i.e., both climate and land cover differ in the two scenarios). The relative importance of climate, land cover, and interactions on the water domain indicators can be determined by analyzing results from all combinations of the suite of land-cover change scenarios (Table 1) and both $\mathrm{C}$ emission (climate) scenarios (Fig. 7).
The relative importance of climate and land cover varies among the indicators. For Fish Habitat Loss, climate dominates the response as the high emission scenarios have greater habitat loss than the corresponding low emission scenario across all landcover scenarios (Fig. 7a). Specific land-cover scenarios modify only moderately the degree of fish habitat loss. Fish habitat loss is primarily driven by temperature impairment in headwater streams (Fig. A4.4b), resulting in a 4- to 10-times increase in river kilometers impacted in the high compared with low emission scenarios (Fig. 5a, 7a). The Backyard scenario exacerbates fish habitat changes caused by climate, whereas the three other landcover scenarios remain similar. The Fish Habitat indicator is composed of flow, water temperature, and chloride impairment (Table 2). The greater degradation in Backyard occurs because of 
the greater abundance of impervious surfaces, with increased runoff from the land leading to greater spatial and temporal probability of crossing chloride and water temperature thresholds. Residential development and associated impervious surfaces in the Backyard scenario result in greater summertime heat flux to streams through stormwater runoff relative to other build-out scenarios. In the Community (both Small Community Food and Large Community Wild) scenarios, reduced effective imperviousness from coupling low-impact design buildout with concentrated development results in negligible increases in heat flux impacts to rivers and no additional fish habitat loss relative to current land cover and projected climates.

For Nitrogen Export, climate is also the primary determinant of indicator response, but interactions with land cover are also evident (Fig. 7b). The Nitrogen Export indicator is higher in all higher emission scenarios relative to lower emission scenarios. Higher emissions scenarios result in greater coastal $\mathrm{N}$ flux than lower emissions scenarios due to greater loading to the river system. First, the greater precipitation in high relative to low emission scenario results in higher atmospheric $\mathrm{N}$ inputs as well as higher water runoff. Second, greater forest $\mathrm{N}$ leaching results from higher temperatures under future scenarios due to declining uptake by conifers. Third, the river system has reduced capacity to retain $\mathrm{N}$ under higher flow regimes (Wollheim et al. 2008b). Small Community Food shows little response under the low emission climate scenario (as discussed above) similar to if land cover remained unchanged. Both the Large Community Wildlands and Backyard scenarios show additional $\mathrm{N}$ export increases relative to other land-cover scenarios, indicating an interaction between land cover and climate. These scenarios have similar high populations compared with Small Community Food, and result in $\mathrm{N}$ loading into rivers via domestic waste, either through septic systems (Backyard) or WWTPs (Large Community), which lead to increased waste $\mathrm{N}$ inputs.

The Large Community Wildlands scenario projects greater $\mathrm{N}$ export than the Backyard scenario (Fig. 7b), despite the former conserving more forest, and upgrading WWTPs to higher treatment levels with lower per capita human waste $\mathrm{N}$ inputs. The logistic loading function that is used to parameterize nonpoint $\mathrm{N}$ inputs to rivers as a function of land cover (Appendix 3) assumes relatively low $\mathrm{N}$ increases for low to moderate density urban and agricultural development (average increases to about $21 \%$ urban $+\mathrm{Ag}$ land cover for Backyard and 9\% for Large Community Wildlands). The mechanistic explanation for this pattern is that $\mathrm{N}$ removal by terrestrial ecosystems remains high up to certain thresholds of natural ecosystem loss, consistent with a number of previous studies (Groffman et al. 2004, Wollheim et. 2005). The Backyard scenario assumes a low density of future land-cover change that is often below the threshold. Thus, human waste associated with population growth, which is managed through distributed septic systems and not WWTP, is mostly retained, and there is relatively little change in $\mathrm{N}$ inputs. In contrast, the Large Community Wildlands scenario assumes domestic waste $\mathrm{N}$ is transferred to WWTP with Total Nitrogen (TN) removal efficiencies of $90 \%$. The assumption of low response to land-cover change embedded in the loading function is derived from one location with a certain social and biogeophysical context (e.g., rural/suburban septic infrastructure, wetland abundance, etc. Wollheim et al. 2008b). Although the generality of this loading function to the entire domain should be tested more thoroughly, the validation results suggest it is reasonable and therefore useful for exploring potential future responses.

An additional small driver of the difference in $\mathrm{N}$ export between Backyard and Large Community Wildlands was that the former also presents greater opportunity for instream removal than the latter because loading occurs to smaller streams (as nonpoint sources) compared with waste water effluent to larger rivers (as point sources). The resulting longer lotic travel time and greater exposure to benthic surfaces provide more opportunities for $\mathrm{N}$ removal through denitrification (Mineau et al. 2015). However, in our simulations, only an additional $1.6 \%$ of total network inorganic $\mathrm{N}$ inputs was removed (denitrified) in the aquatic system under the Backyard scenario compared with Large Community Wildlands.

Water shortfalls are controlled more by land-cover and population scenarios than by climate scenarios (Fig. $7 c$ ). The lack of a strong climate driver occurs because conditions are expected to become increasingly wet under both lower and higher emissions scenarios, alleviating water shortages. The highly dispersed development of the Backyard scenario places an increasing population throughout headwater catchments, dependent on well water. In contrast, the Community scenario places more people on public water supplies that obtain their water from larger catchments. The Water Shortfall indicator we used relates water demand accumulated through the river network (a function of population and per capita demand) with surface water discharge in the grid cell. In the Backyard scenario, people are presumed to depend primarily on wells, not urban water supply infrastructure, where small catchments have limited hydrological storage. Thus, demand more frequently outstrips supply in these local areas. Runoff increases in the higher emission scenario compared with the lower emission scenario, which reflects a combination of greater annual precipitation predicted under a warmer climate and greater forest water-use efficiency under a $\mathrm{C}$-enriched atmosphere (Fig. A4.4c, d). As a result, the high emission scenario actually reduces water shortfalls relative to the low emission scenario (Fig. 7c).

Flood risk is projected to increase under both emission scenarios (Fig. 7d), resulting from greater precipitation (Fig. A4.4c) occurring during extreme events (Hayhoe et al. 2007, Trenberth 2011). Backyard and Large Community Wildlands scenarios project a larger flood-affected population due simply to the larger populations compared with other scenarios. Generally, the higher emission scenario has greater flood risk than the lower emission scenario, with the exception of the Backyard scenario. High emissions are expected to have slightly higher precipitation and runoff relative to low emissions. The Backyard scenario differs in that more people live further north in the watershed than in the Community scenario (concentrated on existing urban areas, Fig. 1 ), which may expose these populations to more extreme flows.

\section{Spatial variability of fish habitat loss}

The spatially distributed modeling approach used here is able to identify changes in environmental indicators relative to human settlement. As an example, the Fish Habitat Loss indicator, as the fraction of years with unsuitable habitat, is greatest in the southern part of the study domain (Fig. 8). Greater impairment in the southern portion of the watershed occurs because warmer 
Fig. 8. Map showing the spatial variability of one of the critical ecosystem service indicators (Fish Habitat Loss) as proportion of years when fish habitat loss exceeds impaired levels for the study domain under (a) Contemporary (1980-2005), (b) Backyard Amenities (2075-2100) high emission (top) and low emission (bottom), and (c) Community Amenities (2075-2100) high emission (top) and low emission (bottom). Location of urban population (density $>200 / \mathrm{km}^{2}$ ) is shown in red in each scenario.

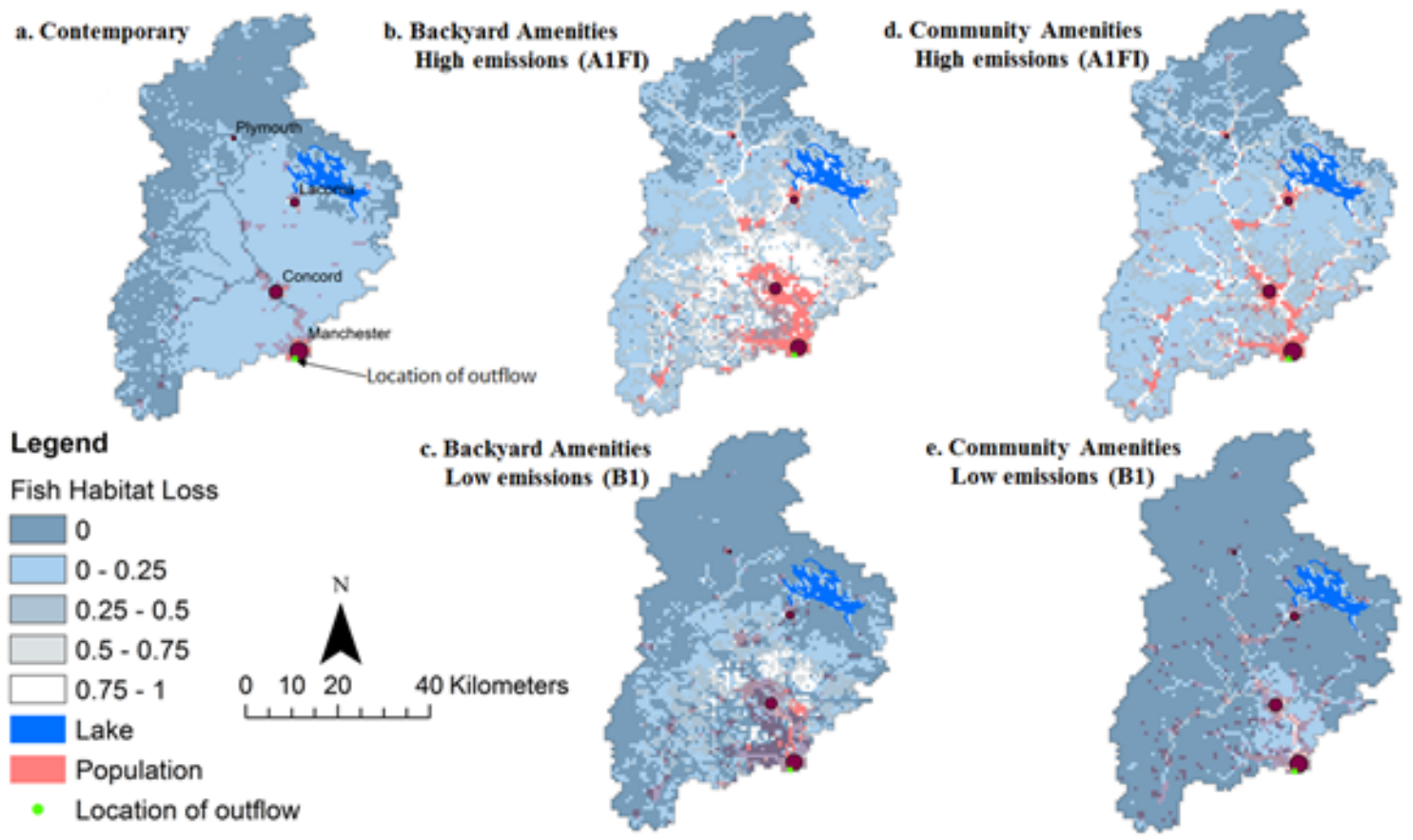

air temperatures increase water temperatures as rivers flow from north to south (Stewart et al. 2011) and because denser road networks relative to the northern portions of the watershed experience greater winter road-salt application.

The Contemporary period shows elevated fish habitat loss in the smaller streams in the southern half of the watershed, but not in the larger rivers (Fig. 8a). Meteorological droughts in 1981 and 1993 are responsible for the contemporary fish habitat loss, which was caused by the low flow component of the indicator. It is possible that future climate from the GFDL GCM used in these scenarios does not capture longer periods of summer dry conditions later in the 20th century (Hayhoe et al. 2007, Wake et al. 2014). Thus, the scenarios presented here may underestimate the effect of the low-flow criteria on future fish habitat loss (Fig. 8).

Future scenarios are likely to intensify fish habitat loss near population centers in the high emission scenarios (Fig. $8 b, d$, top), while spreading through more of the previously unimpaired part of the watershed. In contrast, the low emission scenarios tend to shrink the footprint of the Fish Habitat Loss indicator, although retaining the likelihood of impairment near the population centers (Fig. $8 c, e$, bottom). The Backyard scenario shows a stronger response than the Community scenario because greater impervious cover leads to both increased road-salt loading and increased temperatures from increased summertime impervious surface runoff.
The greater Fish Habitat Loss indicator in large rivers compared with the contemporary period is particularly evident across all future scenarios, resulting in large part because of warmer water temperatures. Large river water temperature responds disproportionately because atmospheric warming further warms water as it flows downstream during summers, whereas headwater streams remain cooler because of groundwater recharged during cooler times of year. The spatially distributed, time-varying modeling approach used here allows consideration of heterogenous impacts to environmental function that can be used in valuation studies.

\section{Role of land-cover management}

Despite the predominant influence of climate on the environmental indicators in the UMRW, land-cover management can mitigate degradation to certain attributes of the ecosystem (e.g., Fig. 8). Build-out scenarios directly influence land-based environmental indicators such as Forest and Agricultural Cover. Scenarios that maintain greater forest land have slightly greater $\mathrm{C}$ sequestration (Fig. A4.4e), whereas scenarios with greater agriculture increase food supply (Thorn et al. 2017) and resiliency (Tilman et al. 2002). In addition, these land covers affect numerous sociocultural resources, including water-related ecosystem services. Depending on the relative value placed on different indicators (Murphy et al. 2017), the landscape can be managed to maximize ecosystem services that are most important. 
Coupled terrestrial-aquatic models express the understanding of processes relevant to specific land-cover decisions, permit exploration of relevant tradeoffs (Antle and Capalbo 2001, Bennett et al. 2009), and are essential in understanding the response of ecosystem dynamics to changes in both climate and land cover. Results from PnET-FrAMES provide a measure of the potential impact of each land-cover scenario and each climate scenario on different ecosystem service indicators. As regional managers have little influence over climate change and because we are currently on a higher emission trajectory (Pachauri et al. 2014), managers should consider potential land cover in conjunction with the higher emissions climate scenario to guide future planning. Projections from PnET-FrAMES suggest that infilled development (Community) scenarios exhibit two types of paradigms with respect to specific aquatic environmental indicators under a high emission future (Fig. 7). The three landcover scenarios with limited expansion of the residential footprint (Constant, Small Community Food, Large Community Wild) show smaller levels of Fish Habitat Loss and Water Shortfalls than the dispersed buildout (Backyard). The Large Community Wildlands scenario represents a doubling of population similar to Backyard scenario, but has much lower environmental detriment based on these two indicators. However, the Large Community Wildlands scenario does show increased impact on the Nitrogen Export indicator (more point sources) and Flood Risk indicator (more people along large river corridors) relative to Backyard, suggesting that there are tradeoffs that must be further managed under an infilled paradigm.

The scenarios tested are simple and do not encompass numerous potential approaches that managers may use to mitigate the adverse effects of the investigated environmental stressors. The scenarios do not account for potential nonpoint $\mathrm{N}$ runoff controls including managed riparian buffers (Mayer et al. 2005) or stormwater control (Collins et al. 2010) that would be consistent with Community scenarios. Nor do the scenarios account for novel flood control measures such as blue-green infrastructure (Thorne et al. 2015) or explicit development outside of flood zones, because flood zones are mapped at resolutions finer than our simulations. Therefore, the flood risk identified here may potentially be mitigated through engineered interventions. Finally, potential management interventions such as constructed stream refugia (Sedell et al. 1990, Isaak et al. 2015) are not considered but could mediate warming stream temperatures for instream biota, a threat under all build-out scenarios. The scenarios presented here identify those environmental stressors that are most likely to need more directed research and management to mitigate changing populations and expected warming.

\section{CONCLUSION}

Process-based terrestrial-aquatic models are essential for quantifying potential future environmental impacts due to spatially distributed changes in land cover and climate. Here, we simulated dynamic interactions across land and water domains at a daily temporal resolution and a spatial resolution that accounts for the heterogeneity and associated processes of the UMRW in New Hampshire. Our approach linked models of intermediate complexity to connect terrestrial and aquatic domains and allowed us to explore the impacts of changes in climate and land cover on aquatic ecosystems through the use of different scenario combinations. Process-based models enable understanding of macroscale ecosystem responses based on underlying ecosystem processes.

Water is arguably the most fundamental resource for society, and it is therefore critical to quantify how water quantity and quality will respond to projected changes in land cover and climate. Our results suggest that climate is expected to be the most influential driver of water-related impairment in the UMRW, although impacts to climate and aquatic environment conditions are likely to be modest until mid-century. After 2050, aquatic impacts are projected to increase rapidly in the high emission scenario, and degree of change is further influenced by land cover. Because recent analysis points to the likelihood of a high emissions scenario (Pachauri et al. 2014), the region should prepare for changes in ecosystem services. Land-cover management is the leverage point that local and state decision makers have to adapt to global climate change, and management interventions that mitigate changes in population and temperature will need to move beyond simple land-cover/land-use formulations analyzed here.

Responses to this article can be read online at: http://www.ecologyandsociety.org/issues/responses. php/9662

\section{Acknowledgments:}

We gratefully acknowledge the technical assistance of $S$. Glidden and A. Proussevitch, the support of all Lotic Volunteer Temperature, Electrical Conductance, and Stage (LoVoTECS) volunteers and coordinators (M. Green, E. Volitis and A. Inserillo) as well as Bill McDowell, Lisle Snyder, and Jody Potter coordinating the High Intensity Aquatic Network (HIAN). LoVoTECS and $H I A N$ data used herein is available at the Data Discovery Center (ddc.unh.edu). This research was funded by the NSF EPSCoR Ecosystems and Society (EPS: 1101245), and the Town of Durham and UNH facilities. Partial funding was provided by the National Sea Grant College Program of the U.S. Department of Commerce's National Oceanic and Atmospheric Administration, grant NA10OAR4170082 to the N.H. Sea Grant College Program, and by the New Hampshire Agricultural Experiment Station. This is NHAES Scientific Contribution Number: 2736. This work was supported by the USDA National Institute of Food and Agriculture (Hatch) Project (Project Number: 0225006).

\section{LITERATURE CITED}

Aber, J. D., S. V. Ollinger, C. T. Driscoll, C. A. Federer, and P. B. Reich. 2005. PnET models: carbon, nitrogen, water dynamics in forest ecosystems (vers. 4 and 5). Model product. Oak Ridge National Laboratory Distributed Active Archive Center, Oak Ridge, Tennessee, USA. http://dx.doi.org/10.3334/ORNLDAAC/817

Antle, J. M., and S. M. Capalbo. 2001. Econometric-process models for integrated assessment of agricultural production systems. Agricultural Economics 83(2):389-401. http://dx.doi. org/10.1111/0002-9092.00164

Bagstad, K. J., D. J. Semmens, S. Waage, and R. Winthrop. $2013 a$. A comparative assessment of decision-support tools for 
ecosystem services quantification and valuation. Ecosystem Services 5:e27-e39. http://dx.doi.org/https://doi.org/10.1016/j. ecoser.2013.07.004

Bagstad, K. J., D. J. Semmens, and R. Winthrop. 2013b. Comparing approaches to spatially explicit ecosystem service modeling: a case study from the San Pedro River, Arizona. Ecosystem Services 5:e40-e50. http://dx.doi.org/https://doi. org/10.1016/j.ecoser.2013.07.007

Bennett, E. M., G. D. Peterson, and L. J. Gordon. 2009. Understanding relationships among multiple ecosystem services. Ecology Letters 12:1394-1404. http://dx.doi.org/10.1111/ j.1461-0248.2009.01387.x

Boumans, R., R. Costanza, J. Farley, A. M.Wilson, R. Portela, J. Rotmans, F. Villa, and M. Grasso. 2002. Modeling the dynamics of the integrated earth system and the value of global ecosystem services using the GUMBO model. Ecological Economics 41:529560 http://dx.doi.org/10.1016/S0921-8009(02)00098-8

Boumans, R., J. Roman, I. Altman, and L. Kaufmanc. 2015. The multiscale integrated model of ecosystem services (MIMES): simulating the interactions of coupled human and natural systems. Ecosystem Services 12:30-41. http://dx.doi.org/10.1016/ j.ecoser.2015.01.004

Boyd, J. 2004. What's nature worth? Using indicators to open the black box of ecological valuation. Resources 154:18-22.

Brauman, K. A., G. C. Daily, T. K. Duarte, and H. A. Mooney. 2007. The nature and value of ecosystem services: an overview highlighting hydrologic services. Annual Review of Environmental Resources 32:6.1-6.32. http://dx.doi.org/10.1146/annurev. energy.32.031306.102758

Burakowski, E. A., P. Cameron, W. B. Braswell, and D. P. Brown. 2008. Trends in wintertime climate in the northeastern United States: 1965-2005. Geophysical Research 113: D20114. http://dx. doi.org/https://doi.org/10.1029/2008JD009870

Burkhard, B., F. Kroll, S. Nedkov, and F. Müller. 2012. Mapping ecosystem service supply, demand and budgets. Ecological Indicators 21:17-29. http://dx.doi.org/10.1016/j.ecolind.2011.06.019

Carpenter, S. R., E. G. Booth, S. Gillon, C. J. Kucharik, S. Loheide, A. S. Mase, M. Motew, J. Qiu, A. R. Rissman, J. Seifert, E. Soylu, M. Turner, and C. B. Wardropper. 2015. Plausible futures of a social-ecological system: Yahara watershed, Wisconsin, USA. Ecology and Society 20(2): 10. http://dx.doi. org/10.5751/ES-07433-200210

Chen, L. D., L. Yang, W. Wei, Z. T. Wang, B. R. Mo, and G. J. Cai. 2013. Towards sustainable integrated watershed ecosystem management: a case study in Dingxi on the Loess Plateau, China. Environmental Management 51:126-137. http://dx.doi.org/10.1007/ s00267-011-9807-0

Coe, M. T. 2000. Modeling terrestrial hydrological systems at the continental scale: testing the accuracy of an atmospheric GCM. Climate 13:686-704. http://dx.doi.org/10.1175/1520-0442(2000) 013<0686:MTHSAT>2.0.CO:2

Collins, K. A., T. J. Lawrence, E. K. Stander, R. J. Jontos, S. S. Kaushal, T. A. Newcomer, N. B. Grimm, and M. L. Cole Ekberg. 2010. Opportunities and challenges for managing nitrogen in urban stormwater: a review and synthesis. Ecological Engineering 36(11):1507-1519. http://dx.doi.org/10.1016/j.ecoleng.2010.03.015

Contosta, A. R., A. Adolph, D. Burchsted, E. Burakowski, M. Green, D. Guerra, M. Albert, J. Dibb, M. Martin, W. H. McDowell, M. Routhier, C. Wake, R. Whitaker, and W. Wollheim. 2017. A longer vernal window: the role of winter coldness and snowpack in driving spring transitions and lags. Global Change Biology 23:1610-1625. http://dx.doi.org/10.1111/gcb.13517

Costanza, R., A. Voinov, R. Boumans, T. Maxwell, F. Villa, L. Wainger, and H. Voinov. 2002. Integrated ecological economic modeling of the Patuxent River watershed, Maryland. Ecological Monographs 72:203-231. http://dx.doi.org/10.1890/0012-9615 (2002)072[0203:IEEMOT]2.0.CO;2

de Groot, R. S., R. Alkemade, L. Braat, L. Hein, and L. Willemen. 2010. Challenges in integrating the concept of ecosystem services and values in landscape planning, management and decision making. Ecological Complexity 7:260-272. http://dx.doi. org/10.1016/j.ecocom.2009.10.006

Goodridge, B. M., and J. M. Melack. 2012. Land use control of stream nitrate concentrations in mountainous coastal California watersheds. Geophysical Research 117:G02005. http://dx.doi. org/10.1029/2011JG001833

Green, M. B., W. M. Wollheim, N. B. Basu, G. Gettel, P. S. Rao, N. Morse, and R. Stewart. 2009. Effective denitrification scales predictably with water residence time across diverse systems. Nature Proceedings 713.

Groeneveld, J., B. Müller, C. Buchmann, G. Dressler, C. Guo, N. Hase, F. Hoffmann, F. John, C. Klassert, T. Lauf, V. Liebelt, H. Nolzen, N. Pannicke, J. Schulze, H. Weise, and N. Schwarz. 2017. Theoretical foundations of human decision-making in agentbased land use models - a review. Environmental Modelling and Software 87:39-48. http://dx.doi.org/10.1016/j.envsoft.2016.10.008

Groffman, P. M., N. L. Law, K. T. Belt, L. E. Band, and G. T. Fisher. 2004. Nitrogen fluxes and retention in urban watershed ecosystems. Ecosystems 7:393-403. http://dx.doi.org/https://doi. org/10.1007/s10021-003-0039-X

Hale, R. L., L. Turnbull, S. Earl, N. Grimm, K. Riha, G. Michalski, K. A. Lohse, and D. Childers. 2014. Sources and transport of nitrogen in arid urban watersheds. Environmental Science and Technology 48(11):6211-6219. http://dx.doi. org/10.1021/es501039t

Harbaugh, A. W. 2005. MODFLOW-2005, the U.S. Geological Survey modular ground-water model-the ground-water flow process. U.S. Geological Survey techniques and methods 6-A16. U.S. Geological Survey, Reston, Virginia, USA. [online] URL: http://pubs.usgs.gov/tm/2005/tm6A16/

Hayhoe, K., C. P. Wake, T. G. Huntington, L. Luo, M. D. Schwartz, J. Sheffield, E. Wood, B. Anderson, J. Bradbury, A. DeGaetano, T. J. Troy, and D. Wolfe. 2007. Past and future changes in climate and hydrological indicators in the US Northeast. Climate Dynamics 28:381-407. http://dx.doi. org/10.1007/s00382-006-0187-8

Heckbert, S., T. Baynes, and A. Reeson. 2010. Agent-based modeling in ecological economics. Annals of the New York 
Academy of Sciences 1185:39-53. http://dx.doi.org/10.1111/ j.1749-6632.2009.05286.x

Heckbert, S., R. Costanza, and L. Parrott. 2014. Achieving sustainable societies: lessons from modelling the Ancient Maya. The Solutions Journal 5(5):55-64.

Hodgkins, G. A., and R. W. Dudley. 2006. Changes in the timing of winter-spring high streamflows in eastern North America 1913-2002. Geophysical Research Letter 33(6):1-5 http://dx.doi. org/https://doi.org/10.1029/2005GL025593

Horton, R., G. Yohe, W. Easterling, R. Kates, M. Ruth, A. Whelchel, D. Wolfe, F. Lipschultz, and E. Sussman. 2014. Northeast. Chapter 16 in J. M. Melillo, T. C. Richmond, and G. W. Yohe, editors. Climate change impacts in the United States: the third national climate assessment. U.S. Global Change Research Program, U.S. Government, Washington, D.C., USA.

Isaak, D. J., M. K. Young, D. E. Nagel, D. L. Horan, and M. C. Groce. 2015. The cold-water climate shield: delineating refugia for preserving salmonid fishes through the 21st century. Global Change Biology 21(7):2540-2553. http://dx.doi.org/10.1111/ gcb. 12879

Iverson, L. R., A. M. Prasad, S. N. Matthews, and M. Peters. 2008. Estimating potential habitat for 134 eastern US tree species under six climate scenarios. Forest Ecology and Management 254:390-406. http://dx.doi.org/10.1016/j.foreco.2007.07.023

Karabulut, A. B. N. Egoh, D. Lanzanova, B. Grizzetti, G. Bidoglio, L. Pagliero, F. Bouraoui, A. Aloe, A. Reynaud, J. Maes, I. Vandecasteele, and S. Mubareka. 2015. Mapping water provisioning services to support the ecosystem-water-foodenergy nexus in the Danube river basin. Ecosystem Services 17:278-292. http://dx.doi.org/10.1016/j.ecoser.2015.08.002

Lee, S. Y., M. E. Ryan, A. F. Hamlet, W. J. Palen, and J. J. Lawler. 2015. Correction: projecting the hydrologic impacts of climate change on montane wetlands. PLoS ONE 10(11): e0142960. http://dx.doi.org/10.1371/journal.pone.0142960

Liang, X., D. P. Lettenmaier, E. F. Wood, and S. J. Burges. 1994. A simple hydrologically based model of land surface water and energy fluxes for GSMs. Geophysical Research 99(D7):14,41514,428 .

Logsdon, R. A., and I. Chaubey. 2012a. Ecosystem services: a need to move from concept to application. Resource May/June: 31. http://dx.doi.org/https://doi.org/10.1016/j.ecolmodel.2013.02.009

Logsdon, R. A., and I. Chaubey. 2012b. A quantitative approach to evaluating ecosystem services: Wildcat Creek Watershed (WCW) in central Indiana. Ecological Modelling 257:57-65.

Lotic Volunter Temperature, Electrical Conductivity, and Stage Sensing Network (LoVOTECS). 2012. The Lotic Volunter Temperature, Electrical Conductivity, and Stage Sensing Network Newsletter. LoVoTECS Network, Plymouth State University and NH EPSCoR 1:1-4.

Mavrommati, G., M. Borsuk, and R. B. Howarth. 2017. A novel deliberative multicriteria evaluation approach to ecosystem service valuation. Ecology and Society 22(2): 39. http://dx.doi. org/10.5751/ES-09105-220239
Mayer, P., S. K. Reynolds, Jr., T. J. Canfield, and M. D. McCutchen. 2005. Riparian buffer width, vegetative cover, and nitrogen removal effectiveness: a review of current science and regulations. U.S. Environmental Protection Agency, National Risk Management Research Laboratory, Ada, Oklahoma, USA.

Miara, A., and C. J. Vörösmarty. 2013. A dynamic model to assess tradeoffs in power production and riverine ecosystem protection. Environmental Science Processes and Impacts 15:1113-1126. http://dx.doi.org/10.1039/c3em00196b

Mineau, M. M., W. M. Wollheim, and R. J. Stewart. 2015. An index to characterize the spatial distribution of land use within watersheds and implications for river network nutrient removal and export. Geophysical Research Letter 42:6688-6695. http://dx. doi.org/10.1002/2015GL064965

Müller, F., and B. Burkhard. 2012. The indicator side of ecosystem services. Ecosystem Services 1:26-30. http://dx.doi.org/10.1016/j. ecoser.2012.06.001

Mulukutla, G. K., B.T. Godbois, and F. Serita. 2015. Deployment of a large-scale soil moisture geosensor network- experience and lessons learnt. ACM SISGPATIAL Magazine 7(2):3-13.

Murphy, M., G. Mavrommati, V. R. Mallampalli, R. B. Howarth, and M. E. Borsuk. 2017. Comparing group deliberation to other forms of preference aggregation in valuing ecosystem services. Ecology and Society 22(4):17. http://dx.doi.org/10.5751/ ES-09519-220417

Nakicenvoic, N., and R. Swart, editors. 2000. Special report on emissions scenarios. Working Group III, Intergovernmental Panel on Climate Change, Geneva, Switzerland and Cambridge University Press, Cambridge, UK.

Nelson, E., G. Mondoza, J. Regetz, S. Polasky, J. Tallis, D. R. Cameron, K. M. A. Chan, G. C. Daily, J. Goldstein, P. M. Kareiva, E. Londsdorf, R. Naidoo, T. H. Ricketts, and M. R. Shaw. 2009. Modelling multiple ecosystems services, biodiversity conservation, commodity production, and tradeoffs at landscape scale. Frontiers in Ecology and the Environment 7(1):4-11. http://dx.doi. org/https://doi.org/10.1890/080023

Notter, B. H. Hurni, U. Wiesmann, and K. C. Abbaspour. 2012 Modelling water provision as an ecosystem service in a large East African river basin. Hydrology and Earth System Science 16:6986. http://dx.doi.org/10.5194/hess-16-69-2012

Ollinger, S. V., J. D. Aber, P. B. Reich, and R. J. Freuder. 2002. Interactive effects of nitrogen deposition, tropospheric ozone, elevated $\mathrm{CO} 2$ and land use history on the carbon dynamics of northern hardwood forests. Global Change Biology 8:545-562. http://dx.doi.org/10.1046/j.1365-2486.2002.00482.x

Ollinger, S. V., C. L. Goodale, K. Hayhoe, and J. P. Jenkins. 2008. Potential effects of climate change and rising CO2 on ecosystem processes in northeastern U.S. forests. Mitigation and Adaptation Strategies for Global Change 13:467-485. http://dx.doi. org/10.1007/s11027-007-9128-Z

Pachauri, R. K., M. R. Allen, V. R. Barros, J. Broome, W. Cramer, R. Christ, J. A. Church, L. Clarke, Q. Dahe, P. Dasgupta, and others. 2014. Climate change 2014: synthesis report. Contribution of Working Groups I, II, and III to the Fifth Assessment Report, 
Intergovernmental Panel on Climate Change, Geneva, Switzerland.

Pellerin, B. A., B. A. Bergamaschi, P. S. Murdoch, B. D. Downing, J. F. Saraceno, G. R. Aiken, and R. G. Striegl. 2011. The aquatic real-time monitoring network; in-situ optical sensors for monitoring the nation's water quality. Fact Sheet 2011-3061, U.S. Geological Survey, Washington, D.C., USA.

Poff, N. L., J. D. Allan, M. B. Bain, J. R. Karr, K. L. Prestegaard, B. D. Richter, R. E. Sparks, and J. C. Stromberg. 1997. The natural flow regime: a paradigm for river conservation and restoration. BioScience 47:769-784. http://dx.doi.org/10.2307/1313099

Qiu, J., and M. G. Turner. 2015. Importance of landscape heterogeneity in sustaining hydrologic ecosystem services in an agricultural watershed. Ecosphere 6(11):1-19. http://dx.doi. org/10.1890/ES15-00312.1

Queiroz, C., M. Meacham, K. Richter, A. V. Norström, E. Andersson, J. Norberg, and G. Peterson. 2015. Mapping bundles of ecosystem services reveals distinct types of multi-functionality within a Swedish landscape Ambio 44(Suppl. 1):S89-S101. http:// dx.doi.org/https://doi.org/10.1007/s13280-014-0601-0

Raymond, P. A., and J. E. Saiers. 2010. Event controlled DOC export from forested watersheds. Biogeochemistry 100:197-209. http://dx.doi.org/10.1007/s10533-010-9416-7

Schroeter, D., W. Cramer, R. Leemans, I. C. Prentice, M. B. Araujo, N. W. Arnell, A. Bondeau, H. Bugmann, T. R. Carter, C. A. Gracia, A. C. de la Vega-Leinert, M. Erhard, F. Ewert, and others. 2005. Ecosystem service supply and vulnerability to global change in Europe. Science 310:1333-1337. http://dx.doi. org/10.1126/science.1115233

Sedell, J. R., G. H. Reeves, F. R. Hauer, J. A. Stanford, and C. P. Hawkins. 1990. Role of refugia in recovery from disturbances: modern fragmented and disconnected river systems. Environmental Management 14(5):711-724. http://dx.doi.org/10.1007/BF02394720

Soylu, M. E., C. J. Kucharik, and S. P. Loheide, II. 2014. Influence of groundwater on plant water use and productivity: development of an integrated ecosystem-variably saturated soil water flow model. Agricultural and Forest Meteorology 189-190(1):198-210. http://dx.doi.org/10.1016/j.agrformet.2014.01.019

Stein, S. M., R. E. McRoberts, L. G. Mahal, M. A. Carr, R. J. Alig, S. J. Comas, D. M. Theobald, and A. Cundiff. 2009. Private forests, public benefits: increased housing density and other pressures on private forests contributions. General Technical Report, U.S. Department of Agriculture, Forest Service, Pacific Northwest Research Station, Portland, Oregon, USA. http://dx. doi.org/10.2737/PNW-GTR-795

Stewart, R. J., W. M. Wollheim, M. N. Gooseff, M. A. Briggs, J. M. Jacobs, B. J. Peterson, and C. S. Hopkinson. 2011. Separation of river network-scale nitrogen removal among the main channel and two transient storage compartments. Water Resources Research 47(10):W00J10, http://dx.doi.org/10.1029/2010WR009896

Stewart, R. J., W. M. Wollheim, A. Miara, C. J. Vörösmarty, B. Fekete, R. B. Lammers, and B. Rosenzweig. 2013. Horizontal cooling towers: riverine ecosystem services and the fate of thermoelectric heat in the contemporary Northeast US.
Environmental Research Letters 8(2):025010. http://dx.doi. org/10.1088/1748-9326/8/2/025010

Stoner, A. M. K., K. Hayhoe, X. Yang, and D. J. Wuebbles. 2012. An asynchronous regional regression model for statistical downscaling of daily climate variables. Journal of Climatology 33 (11):2473-2494. http://dx.doi.org/10.1002/joc.3603

Tallis, H., and S. Polasky. 2009. Mapping and valuing ecosystem services as an approach for conservation and natural-resource management. New York Academy of Sciences 1162:265-283. http://dx.doi.org/10.1111/j.1749-6632.2009.04152.x

Tallis, H. T., T. Ricketts, A. Guerry, A. S. Wood, R. Sharp, E. Nelson, D. Ennaanay, S. Wolny, N. Olwero, K. Vigerstol, D. Pennington, G. Mendoza, J. Aukema, J. Foster, J. Forrest, D. Cameron, K. Arkema, E. Lonsdorf, C. Kennedy, G. Verutes, C. Kim, G. Guannel, M. Papenfus, J. Toft, M. Marsik, J. Bernhartdt, R. Griffin. 2013. InVEST2.6.0 user's guide. The Natural Capital Project, Stanford, California, USA.

Thorn, A. M., C. P. Wake, C. Grimm, C. Mitchell, M. M. Mineau, and S. V. Ollinger. 2017. Development of scenarios for land cover, population density, impervious cover, and conservation in New Hampshire, 2010-2100. Ecology and Society 22(4):19. http://dx. doi.org/10.5751/ES-09733-220419

Thorne, C. R., E. C. Lawson, C. Ozawa, S. L. Hamlin, and L. A. Smith. 2015. Overcoming uncertainty and barriers to adoption of blue-green infrastructure for urban flood risk management: uncertainties and barriers to adoption of BGI. Journal of Flood Risk Management, online early. http://dx.doi.org/10.1111/ ifr3.12218

Tilman, D., K. G. Cassman, P. A. Matson, R. Naylor, and S. Polasky. 2002. Agricultural sustainability and intensive production practices. Nature 418:671-677. http://dx.doi. org/10.1038/nature01014

Trenberth, K. E. 2011. Changes in precipitation with climate change. Climate Research 47:123-138. http://dx.doi.org/10.3354/ $\underline{\mathrm{cr} 00953}$

U.S. Environmental Protection Agency (USEPA). 2010. ICLUS tools and datasets (version 1.3.2). U.S. Environmental Protection Agency, Washington, D.C., USA.

van Oudenhoven, A. P. E., K. Petz, R. Alkemade, L. Hein, and R. S. de Groot. 2012. Framework for systematic indicator selection to assess effects of land management on ecosystem services. Ecological Indicators 21:110-122. http://dx.doi. org/10.1016/j.ecolind.2012.01.012

Vigerstol, K. L., and Aukema, J. E. 2011. A comparison of tools for modeling freshwater ecosystem services. Environmental Management 92:2403-2409. http://dx.doi.org/https://doi.org/10.1016/ j.jenvman.2011.06.040

Villa, F., M. Ceroni, K. Bagstad, G. Johnson, and S. Krivovet. 2009. ARIES (ARtifcial Intelligence for Ecosystem Services): a new tool for ecosystem services assessment, planning, and valuation. Eleventh International BIOECON Conference on Economic Instruments to Enhance the Conservation and Sustainable Use of Biodiversity, Venice, Italy. [online] URL: http://www.ucl.ac.uk/ bioecon/11th 2009/Villa.pdf 
Vörösmarty, C. J., C. A. Federer, and A. L. Schloss. 1998. Potential evaporation functions compared on US watersheds: possible implications for global-scale water balance and terrestrial ecosystem modeling. Hydrology 207:147-169.

Wake, C., E. Burakowski, P. Wilkinson, K. Hayhoe, A. Stoner, C. Keeley, and J. LaBranche. 2014. Climate change in southern New Hampshire past, present, and future. Climate Solutions New England, Durham, New Hampshire, USA.

Wisser, D., B. M. Fekete, C. J. Vörösmarty, and A. H. Schumann. 2010. Reconstructing 20th century global hydrography: a contribution to the Global Terrestrial Network-Hydrology (GTN-H). Hydrology and Earth System Sciences 14:1-24. http:// dx.doi.org/10.5194/hess-14-1-2010

Wollheim, W. M., B. A. Pellerin, C. J. Vörösmarty, and C. S. Hopkinson. 2005. N retention in urbanizing headwater catchments. Ecosystems 8:871-884. http://dx.doi.org/10.1007/ $\underline{\text { s10021-005-0178-3 }}$

Wollheim, W. M., B. J. Peterson, C. J. Vörösmarty, C. Hopkinson, and S. A. Thomas. 2008a. Dynamics of $\mathrm{N}$ removal over annual time scales in a suburban river network. Geophysical Research 113: G03038.

Wollheim, W. M., C. J. Vörösmarty, A. F. Bouwman, P. A. Green, J. Harrison, E. Linder, B. J. Peterson, S. Seitzinger, and J. P. M. Syvitski. 2008b. Global N removal by freshwater aquatic systems: a spatially distributed, within-basin approach. Global Biogeochemical Cycle 22:GB2026.

Wollheim, W. M., C. J. Vörösmarty, B. J. Perterson, S. P. Seitzinger, and C. S. Hopkinson. 2006. Relationship between river size and nutrient removal. Geophysical Research Letters 33: L06410. http:// dx.doi.org/10.1029/2006GL025845

Wood, A. W., E. P. Maurer, A. Kumar, and D. P. Lettenmaier. 2002. Long-range experimental hydrologic forecasting for the eastern United States, Geophysical Research 107(D20):ACL 6-1ACL 6-15. 


\section{Appendix 1. Model Overview}

\subsection{PnET-FrAMES}

To facilitate the simulation of aquatic ecosystem variables in the Upper Merrimack River Watershed (UMRW), we coupled terrestrial aquatic model that simulated forest processes and had regionally specific mechanisms for capturing the influence of developed land covers. We utilized the Photosynthesis and EvapoTranspiration-Carbon-Nitrogen (PnET-CN) for its proven ability to accurately simulate forest processes in New England (Aber and Driscoll 1997, Ollinger et al. 2002, Ollinger et al. 2008) and an aquatic process-based model, the Framework for Aquatic Modeling of the Earth System (FrAMES) for simulation of instream denitrification (Wollheim et al. 2008a, 2008b), routing of discharge and solute fluxes (Zuidema et al. In Prep), and instream temperature re-equilibration with the atmosphere (Stewart et al. 2013) at a daily time-step. The following sections provide detail on the functionality of each model component, and a description of specific parameterizations and linkages required for the coupling of the aquatic and terrestrial ecosystem models.

\subsection{PnET}

PnET-CN is a forest ecosystem model that combines algorithms for processes such as photosynthesis, evapotranspiration, litter production, decomposition, and $\mathrm{N}$ mineralization along with climate inputs to estimate complete fluxes of carbon (C), nitrogen $(\mathrm{N})$, and forest water at a monthly time step (Aber and Driscoll 1997, Ollinger et al. 2002, Ollinger et al. 2008). PnET-CN is used to predict time varying net primary production (NPP), evapotranspiration, carbon storage, wood biomass, and nitrogen 
leaching losses associated with forest type, climate variability, atmospheric nitrogen deposition, and forest succession. The model was developed and validated in the Northeastern U.S. at both site and regional scales (Ollinger et al. 2002, 2008, Aber et al. 2005 and Zhou et al. In Prep). In this study, in order to be coupled with FrAMES, we revised the monthly model into a daily model that adds the role of impervious surfaces and lawns in urban areas to accommodate the coupling with the regional aquatic model (Zhou et al. In Prep). Several processes were revised, such as minor revision of photosynthesis and foliar growth due to non-linear relationship between photosynthesis and climate input. The rain/snow precipitation processes were also modified as precipitation in daily time step normally occurs as either rain or snow in winter. It is not appropriate to split it for rain and snow as in monthly version because monthly precipitation is the sum of rain and/or snow. This improved PnET prediction of snowpack and runoff in winter and early spring (Zhou et al. In Prep).

Reasonable physiological response of atmospheric $\mathrm{CO}_{2}$ and acclimation of respiration are important for future projections of ecosystem functions in the changing environment. Previous version of PnET had a $\mathrm{CO}_{2}$ effect on carbon assimilation using a MichalisMenton equation fitted to normalized A-Ci (photosynthesis assimilation and the internal $\mathrm{CO} 2$ concentration) curves (scaled from 0 to 1 where 1 is $\mathrm{CO}_{2}$ saturated carbon fixation) taken from a number of $\mathrm{CO}_{2}$ exposure studies (Ollinger et al. 2002). More newly existing empirical data from $\mathrm{CO}_{2}$ exposure studies were added to improve the regression. Especially the high end of $\mathrm{CO}_{2}$ concentrations of over $2000 \mathrm{ppm}$ showed much less increased effect in photosynthesis than expected (Franks et al. 2013). The revised 
response function suggested a lower photosynthetic $\mathrm{CO}_{2}$ compensation point of $40 \mathrm{ppm}$ compared to the Ollinger et al.'s 68 ppm. If, for example, a change in $\mathrm{CO}_{2}$ from 350 to 1000 represents the high emission climate scenario, a 59\% increase in photosynthesis will be predicted by the previous function and only $22 \%$ by the revised version. The two equations estimate similar relative change in photosynthesis between ambient and historical $\mathrm{CO}_{2}$, implying the revision only impact future project.

Evidence suggests that respiration acclimation (RA) to temperature in plants can have a substantial influence on ecosystem carbon balance. Previous versions of PnET had not included explicit respiration acclimation in a future warming climate. This study incorporated temperature-sensitive Q10 and foliar respiration acclimation algorithms in the model (Wythers et al. 2013). e.g., at the temperature of $35^{\circ} \mathrm{C}$, the RA algorithms estimate a $37 \%$ reduction in foliar respiration relative to that using previous version. Wythers et al. (2013) reported that averaged across four boreal ecotone sites and three forest types at year 2100, the enhancement of NPP in response to the combination of rising $\mathrm{CO}_{2}$ and warming was $9 \%$ greater when RA algorithms were used, relative to responses using fixed respiration parameters.

Biogeochemical monitoring for 50 years at the Hubbard Brook Experimental Forest in New Hampshire has revealed $\mathrm{N}$ export in stream water has steadily declined and is presently just a small fraction of atmospheric $\mathrm{N}$ input, despite negligible changes in aboveground biomass. It implies that the forested ecosystem has shifted to a net $\mathrm{N}$ sink (Yanai et al. 2013), which could not explained by the previous theory. The "missing" 
deposited $\mathrm{N}$ were thought to accumulate in the mineral soil, or be lost in gaseous form. Processes of $\mathrm{N}$ gas losses (i.e., $\mathrm{N}_{2} \mathrm{O}, \mathrm{NO}$, and $\mathrm{N}_{2}$ ) through nitrification and denitrification were added in PnET-CN to enhance its $\mathrm{N}$ cycling and to investigate the role of denitrification in the missing $\mathrm{N}$ sink (Zhou et al. In Prep). We used first order kinetics to estimate $\mathrm{N}$ gas losses and partitioned $\mathrm{N}_{2} \mathrm{O}, \mathrm{NO}$, and $\mathrm{N}_{2}$ based on soil water content. In this study, the parameter, denitrification constant was set to the averaged value of 0.03 (McCray et al. 2005) to represent a more general pattern for a large region, which could be potentially underestimate in mountainous areas.

\subsection{FrAMES}

FrAMES, the Framework for Aquatic Modeling in the Earth System, is a spatially distributed gridded river network model that has been applied extensively at various spatial scales (Wollheim et al. 2008a, 2008b and Stewart et al. 2011, Vörösmarty et al. 1998, Wisser et al. 2010, Stewart et al. 2013 and Zuidema et al. In Prep). FrAMES incorporates a number of dynamically linked modules that operate on a daily time step. These modules include the Water Balance Model (WBM), the Water Transport Model (WTM) (Vörösmarty et al. 1998; Wisser et al. 2010), suburban dissolved inorganic nitrogen (DIN) loading (Wollheim et al. 2008b), in-stream nitrogen removal (Stewart et al. 2011), the Non-point Thermal Loading Model or NTLM and the River Temperature Re-equilibrium Model (RTRM) (Stewart et al. 2013), the Thermoelectric Power and Thermal Pollution Model (TP2M) (Miara et al. 2013), and the Non-point Anthropogenic Chloride Loading (NACL) module (Zuidema et al. In Prep). Typically, FrAMES has a land surface hydrology component that operates independently of forest dynamics. In this 
study, FrAMES has been coupled with PnET to simulate the dynamic interactions among terrestrial and aquatic processes in the UMRW across a spectrum of land cover and climate projections for the region. Here, we substitute PnET-CN predictions of runoff and nitrogen to load material from forests to river networks.

In the PnET-FrAMES coupling, PnET-CN predicts runoff and DIN leaching from forests, whereas FrAMES simulates inputs of specific conductivity, thermal loads, and DIN loads from urban and agricultural areas. Water from the soil root zone in PnET as runoff is partitioned to surface and groundwater runoff generating pools in FrAMES, which introduce a lag in delivery to the stream network. PnET nitrogen leachate is applied to the daily runoff volume of the linked model. PnET does not consider riparian nitrogen removal, which is parameterized in FrAMES as a zero-order removal process that eliminates $75 \%$ of the forest leachate prior to entering the stream network. This value was determined by calibration to extensive headwater concentration data (Appendix 3) and deserves additional investigation. FrAMES propagates discharge and all solute loads downstream using a cascade routing method at a daily time step. 


\section{Appendix 2. Model Input Data}

\subsection{Simulated river network}

A simulated topological network representing the river network was derived from a HydroSheds digital elevation model (Lehner et al. 2008) at a 45-arc second resolution following Fekete et al. (2001).

\subsection{Contemporary climate data}

Historical climate from NASA Modern Era-Retrospective Analysis for Research and Applications (MERRA) was used to drive the coupled model (PnET-FrAMES) for the period of 1980-2014. Key drivers in the coupled model include average, minimum, and maximum daily air temperature, total daily precipitation, average daily cloud cover and average daily wind speed. MERRA data are at a spatial resolution of $1 / 2$ degree latitude by $2 / 3$ degree longitude.

We adjusted MERRA air temperature to account for elevation effects, which varies from $49 \mathrm{~m}$ to $1416 \mathrm{~m}$ in the upper Merrimack R. watershed (UMRW). We assumed a lapse rate of $6.4^{\circ} \mathrm{C}$ per km of altitude above ground level (NOAA et al. 1976). The elevation difference between the MERRA course scale datasets ( $1 / 2$ by $2 / 3$ degrees) and the 45 -arc second river network grid was used to adjust MERRA air temperature data for altitude. To develop a map of high-resolution daily precipitation for the region we adjusted the gridded MERRA precipitation using data from between 52 and 132 stations (depending on year) in New England from the Global Historical Climatology Network (GHCN), assuming a 50\% interpolation weighing factor. 


\subsection{Contemporary land cover data}

Land cover for the contemporary period (1980-2019) is based on data described in Thorn et al. (this issue) at 30 meter spatial resolution for the period 1996-2010. We resampled land cover to develop percent cover in each 45 arc-second grid cell. PnET-CN distinguishes forest processes in deciduous, coniferous, and mixed categories, which were also acquired from Thorn et al. (this issue) which was estimated directly from the National Oceanic and Atmospheric Administration's Coastal Change Analysis Program data. A separate impervious cover data layer was derived from the National Land Cover Dataset (Xian et al. 2011). We disaggregated developed land cover to impervious and lawn covers by assigning all non-impervious developed land to a lawn land cover type. Finally, we used the spatially distributed population estimate of Thorn et al. (this issue), which is needed as both a model driver (e.g., waste water and domestic chloride inputs) and to develop indicators (see below).

\subsection{Future climate scenarios}

Future climate projections used statistically downscaled climate data derived from the Geophysical Fluid Dynamics Laboratory CM2.1 model. Statistical downscaling from a native $2^{\circ} \times 2.5^{\circ}$ resolution to $7.5^{\prime} \times 7.5^{\prime}$ was performed as described in Hayhoe et al. (2007). We used two scenarios bounding a range of potential future temperature and regional climate: lower $\mathrm{CO}_{2}$ emission (B1, $550 \mathrm{ppm} \mathrm{CO}_{2}$ by 2100) and higher $\mathrm{CO}_{2}$ emission (A1FI, $970 \mathrm{ppm} \mathrm{CO}_{2}$ by 2100). Air temperature were adjusted for elevation as described above, and precipitation was bilinearly interpolated. The downscaled global climate model simulations used for environmental indicators of climate used a different 
statistical downscaling technique (Stoner et al. 2013, Wake et al. 2014) these data were unavailable as gridded data for our model domain. However, a check of projections at the specific location indicate they are consistent.

\subsection{Future land cover scenarios}

To demonstrate the coupled model, and to develop indicators required for the ecosystem services valuation (Mavrommati et al. 2017), we focus on two land cover scenarios expected to show the largest range in changing ES, the "Backyard Amenities" (Backyard) and the "Small Community with Promotion of Local Food" (Small Community Food) (Thorn et al. this issue). Table 1 presents key differences between these land cover scenarios. The Backyard land cover scenario, which prioritizes large building lots and incurs increased transportation related energy consumption, was paired with higher greenhouse gas emission (A1Fi) scenario. Conversely, the Small Community Food scenario reduces transportation-related energy consumption and is more consistent with the lower greenhouse gas emission (B1) scenario. For subsequent analyses into the specific roles of climate and land cover change, we consider the responses of the suite of land cover (Thorn et al. this issue) and emission scenarios.

We simulate future drivers of terrestrial and aquatic ecosystems using projected impervious cover, population density, and land cover from Thorn et al. (this issue) for each future decade from 2020 to 2100 . Land cover and population data was aggregated using the same methodology as for contemporary land cover. We assumed the proportion of each forest type remains constant in the future. 
Table A2.1. Considered Indicators

\begin{tabular}{ll}
\hline Considered Indicators & Domain \\
\hline & Land \\
Climate Regulation & \\
Biofuels & \\
Bioproducts & \\
Farmland & \\
Forest Biodiversity & \\
Forest Type & \\
Carbon Sequestration & Climate \\
Timber Stock & \\
Forest Cover & \\
Agricultural-Livestock & \\
Agricultural-Maple Syrup & \\
Heating + Cooling Degree Days \\
Hot Days \\
Snow Days \\
Snowmaking Days \\
Snow-clearing Impact \\
Winter Road Closure Days \\
Significant Precipitation Days \\
Hemlock Wooly Adelgid Index \\
Fall Foliage Days \\
Summer Days \\
Lyme Disease Risk Index \\
Air Quality Impaired Days \\
Water Provision \\
Shallow Ground Water Supply \\
Total Water Supply \\
Surface Drinking Water (DW) \\
Impairment \\
Shallow Ground DW Impairment \\
Total DWQ Impaired \\
Flood Attenuation (100-Yr) \\
Flood Attenuation (50-Yr) \\
Power Plant Operation Threshold \\
Fish Habitat Thermal Impairment \\
Riverine Environmental Flow \\
Impairment \\
Fish Habitat Chloride Impairment \\
\hline
\end{tabular}


Drinking Water Low Sodium

Impairment

Drinking Water Trace Metals

Impairment

Fish Habitat Nitrate Impairment

River Habitat

Fecal Coliform Impairment

Dissolved Oxygen Impairment

Coastal Health

Considered indicators are sized by the round when an indicator was eliminated from consideration (first, second, third, final). 


\section{Appendix 3. Model Parameterization}

The hydrologic and biogeochemical conditions of a watershed can be significantly altered by land cover change. Due to the broad range in projections for population and impervious surfaces in the UMRW, it is essential that these potential ecosystem changes are accurately accounted for and simulated in the PnET-FrAMES linked model. Several parameterizations were made to adequately account for the changes in solute loading, and runoff timing and magnitude due to these land cover projections.

Simulated runoff in PnET-FrAMES is parameterized to account for changes in watershed impervious surfaces. The linked model partitions direct and in-direct runoff from the fraction of total impervious areas $\left(f_{\text {imp }}\right)$ via the fraction of hydrologically connected imperviousness parameter $\left(f_{h c i}\right)$. We assume during the contemporary period that $f_{h c i}=f_{i m p}$, which is consistent with observations of hydrologic connectivity of impervious areas at moderate total imperviousness $\left(f_{\text {imp }}=0.2\right)$ estimated through hydrologic partitioning at catchment scales in the region (Pellerin et al. 2008). This relationship overestimates the hydrologic connection at low values of total imperviousness (Alley and Veenhuis 1983, Shuster et al. 2005), which we consider consistent with our scales of simulation relative to such studies. In future scenarios, for Small Community Food we alter parameter values to account for low-impact design (LID), while for Backyard we assume no change. For Small Community Food, we assume that LID reduces effective imperviousness progressively into the future. We reduce $f_{h c i}$ each future decade according to $f_{h c i}=\kappa f_{i m p}$ with $\kappa$ decreasing linearly from 1.0 in 2010 to 0.1 in 2060 . In conjunction with the reduction in $f_{h c i}$, available water 
capacity (AWC) of lawn areas is increased to accommodate an additional $25 \mathrm{~mm}$ of precipitation. This increase accounts for increased storage capacity in lawn areas due to LID improvements.

PnET-FrAMES simulates five natural and anthropogenic sources of chloride through the Non-point Anthropogenic Chloride Loading (NACL) module (Zuidema et al. In Prep) to capture salt impairment of aquatic habitat. Road salt (deicer) loading is the predominate source of chloride in the model domain. The flux of road salt to the system ( $m_{D E I}$, units) is the product of frozen (winter) precipitation $\left(P_{w}\left[m m d^{-1}\right]\right)$, fraction of impervious area $\left(f_{\text {imp }}\right)$, fraction of treated impervious area $\left(f_{D E I}\right)$, cell area $(A)$, and rate of road salt loading per mm of snow fall $\left(C_{D E I}\left[\mathrm{~g} \mathrm{Cl} \mathrm{mm}^{-1} \mathrm{~m}^{2}\right]\right.$ or $\left.\left[\mathrm{g} \mathrm{Cl} \mathrm{L}^{-1}\right]\right)$. The fraction of treated impervious area $\left(f_{D E I}\right)$ is an estimate of roads, sidewalks and parking lots that require deicing, set to 0.6 for both scenarios. The road salt loading parameter was estimated to be about $7\left[\mathrm{~g} \mathrm{Cl} \mathrm{L}^{-1}\right]$ in the Merrimack River Watershed (MRW) (Zuidema et al. In Review). The Backyard scenario maintains status quo road salt loading $\left(C_{D E I}=7.0\left[\mathrm{~g} \mathrm{Cl} \mathrm{L}^{-1}\right]\right)$, whereas the Community scenario includes an abrupt transition to recommended levels, to $C_{D E I}^{R E C}=2.5 \mathrm{~g} \mathrm{Cl} \mathrm{L}^{-1}$ in 2015 to simulate improved management.

Inorganic nitrogen loading is a function of forest DIN loading, derived from the forest ecosystem model PnET (see below) and anthropogenic $\mathrm{N}$ loading from developed and agricultural lands (determined from empirical relationships in FrAMES). Suburban and agricultural DIN loading is parameterized according to logistic functions on the fraction of suburban or agricultural land and runoff depth (Wollheim et al. 2008a). 
Patterns of DIN loading with increasing suburban area are as in Wollheim et al. (2008b), with maximum of $1.4 \mathrm{mg} \mathrm{L}-1$, and $\mathrm{xmid}=51.39 \%$ suburban development. This function is nonlinear and assumes little response in DIN loading until some threshold of development is crossed, assuming that natural retention processes prevent losses at lower development. We here assume that maximum DIN loading concentration in agricultural land is 3.5 times higher than in suburban land (Price 2014). To simulate improved management in the Community scenario, maximum DIN loading concentrations from agricultural land is assumed to only be 2 times higher than suburban loading, assuming that best practices and organic agriculture called for in the scenario (Thorn et al. this issue) would result in a $40 \%$ reduction in agricultural DIN export.

WWTPs are a significant point source of DIN load to the upper Merrimack R. watershed (Stewart et al. In Prep). For the contemporary scenario, influent TN fluxes to WWTPs are estimated based on the population served by each plant (USEPA 2008), and a per capita TN emission rate (20 g TN per person per day, Van Drecht et al. 2009). Daily effluent masses of DIN from WWTPs to the river network were estimated based on TN removal efficiencies for each WWTP treatment technology (Van Drecht et al. 2009), and the proportion of effluent TN that is in DIN form (Dumont et al. 2005). In the Backyard scenario, we assume wastewater for new population is managed via septic systems (consistent with dispersed development) so WWTP DIN effluent remains constant (Stewart et al. Unpublished). In the Small Community Food scenario, we allocate all increased waste $\mathrm{N}$ from additional population growth to the nearest downstream existing WWTP, and increase WWTP efficiency to 90\% removal of influent TN. 


\section{Appendix 4. Environmental indicators}

A multidisciplinary group consisting of ecologists, hydrologists, engineers, economists and decision scientists developed a set of potential indicators that encompass a set of climate, terrestrial, and aquatic ecosystem services of importance in the study region.

\subsection{Atmosphere domain}

Three indicators were chosen for the atmosphere/climate domain to represent primarily recreational and regulation ecosystem services. The three indicators were derived from two sources of downscaled atmospheric forcing data: 1) spatial averages of metrics derived from input to the coupled PnET-FrAMES model based on Hayhoe et al. (2007), and 2) station based estimates of down-scaled climate data (Wake et al. 2014) using the asynchronous down-scaling method of Stoner et al. (2013).

Extreme hot days $\left(A_{\text {Hot }}\right)$. The extreme hot days indicator was chosen as an indicator of the atmosphere's regularization service of maintaining temperatures conducive to extended labor outdoors. The indicator was calculated by summing the number of days with maximum daily temperature $\left(T_{\text {Max }}^{i, k}\right)$ exceeding $32^{\circ} \mathrm{C}$ across the watershed, then averaging this value across the watershed.

Snow days $\left(A_{\text {Snow }}\right)$. The snow days indicator was chosen as an indicator of the potential recreational opportunities from ample snow-cover provided by the atmosphere. The indicator was calculated by summing the number of days with a minimum of $30 \mathrm{~mm}$ 
snowpack $\left(S_{P a c k}^{i, k}[m m\right.$ (water equivalents) $]$ ) across the watershed, then averaging this value across the watershed.

Recreation days. The recreation days indicator was chosen as an indicator of the potential recreational opportunities afforded by pleasant temperatures. The indicator was

calculated by summing the number of days with daily max temperatures $\left(T_{\max }^{i, k}\right)$ between $21^{\circ} \mathrm{C}$ and $32^{\circ} \mathrm{C}$, then averaging this value across the watershed.

\subsection{Land domain}

Three indicators were chosen for the land domain that all represent non-use and aesthetic value and provisioning services.

Farm land $\left(L_{\text {Farm }}\right)$. The farm land indicator was calculated directly from build-out scenario data including modeled agricultural land cover and total population within the UMRW. Farm land was expressed as the number of acres of watershed agricultural-land $\left(A_{A g}\right)$ per resident of the $\operatorname{UMRW}(P)$.

Forest cover $\left(L_{\text {Forest }}\right)$. In addition to non-use, aesthetic, and timber provisioning, total forest cover represents potential recreational services, is considered indicative of important services of [carbon sequestration] and maintenance of biodiversity. The forest cover indicator is calculated directly from build-out scenario data and is expressed as the total forest cover in acres for the UMRW. 
Forest type $\left(L_{\text {ForType }}\right)$. In addition to services provided by forest cover, the type of forest, particularly the proportional presence of maple/beech/birch (MBB) is considered important for [tourism] services. The forest type indicator represents the fraction of forest cover considered suitable for MBB. These were taken from New Hampshire average suitability index modeling for present and 2100 for low (B1) and high (A1FI) carbon emission scenarios (Iverson et al. 2008 ${ }^{1}$ ).

\subsection{Water domain}

Four indicators were chosen for the water domain that represent a diversity of ecosystem services. The four indicators were derived from coupled PnET-FrAMES model output forced using the same land cover and climate datasets used to derive indicators for atmosphere and land domains. The four water domain indicators were expressed in terms of potential stressors to relevant ecosystem services. Associated supply and demand of ecosystem services related to water also evolve with urbanization (Wollheim et al. 2015).

Water supply $\left(W_{\text {Supply }}[p d]\right)$. Water supply was chosen as an indicator of potential stress to human provisioning needs. Water supply represents the spatial and annual sums of population potentially affected $\left(P_{\text {Supply }}\right)$ by limited water availability, times the number of days per year persons were potentially affected. To calculate potentially affected population, we first use to calculate the daily flow accumulation $(F A)$ (Tarboton et al. 2009) at each grid cell to estimate water availability for the population in the grid cell $(V)$. We then accumulate the downstream difference between water supply $(Q-$

\footnotetext{
${ }^{1}$ http://www.nrs.fs.fed.us/atlas/
} 
$Q_{\text {env }}$ ) (stream flow minus environmental flow) and total human consumptive demand $\left(U\left[L d^{-1}\right]=P[p] * u\left[L p^{-1} d^{-1}\right]\right)$ where $u$ is a per capita water demand of residents in New Hampshire, which 284 L/p/d (Horn et al. 2008).

$$
V=F A\left(\max \left(Q-Q_{e n v}, 0\right)-U\right)
$$

Affected population $\left(P_{\text {Supply }}^{i, k}\right)$ is then calculated as the maximum of local population or the population that is expected to have insufficient supply, except in densely populated cities $\left(\rho_{\text {pop }}>350 \mathrm{P} \mathrm{km}^{-2}\right)$ where supply is assumed available elsewhere in the watershed. This density is consistent with areas of known public water supply systems in the UMRW. The demand of these areas is transmitted downstream, so the high demand can trigger water shortfalls in downstream cells.

As formulated, $W_{\text {Supply }}$ considers both rural and urban water consumers in a simple consistent framework that is flexible across development patterns. The indicator assumes that streamflow is an appropriate indicator of water supply even where actual abstractions may come from groundwater resources.

Flood attenuation $\left(W_{\text {Flood }}[p d]\right.$ ). Flood attenuation was selected as an indicator of potential impact to human and infrastructure safety. Flood attenuation represents the spatial and annual sums of population potentially affected $\left(P_{F l o o d}\right)$ by local flooding, times the number of days per year persons were potentially affected. To calculate affected population, we assume that the entire population of a grid-cell (at $\sim 1.5 \mathrm{~km} 2$ ) is potentially affected when daily mean discharge in the grid cell from PnET-FrAMES exceeds an 
estimate of the 100-year flood discharge. The threshold defining flood runoff was spatially distributed dependent on mean April precipitation, channel slope, upstream wetland fraction, and catchment area following Olson et al. (2009).

Fish habitat $\left(W_{\text {Fish }}[\mathrm{km}]\right)$. Fish habitat was selected as an indicator of potential non-use or aesthetic value, as well as recreational value of sport fishing. Fish habitat is calculated as the fraction of the total length of all streams and rivers in the watershed that exceed at least one threshold associated with either water temperature, salinity (as chloride), or instream flow at least one time in each year. We use a 7-day rolling mean water temperature and determine when this value exceeds the median of freshwater fish tolerances $\left(29.2^{\circ} \mathrm{C}\right)$ from Eaton and Scheller (1996). We use 4-day rolling mean of chloride to determine when it exceeds the USEPA chronic water quality criteria for chloride (230 $\mathrm{mg} \mathrm{Cl} \mathrm{L}^{-1}$ ) (USEPA 1988). We use the 7-day rolling mean of discharge to determine when it is below an estimate of in-stream flow requirement equal to present day $7 \mathrm{Q} 10$, or the $10^{\text {th }}$-percentile of annual minimum 7-day rolling mean discharges. We estimate present-day 7Q10 in runoff as $0.122\left[\mathrm{~mm} \mathrm{~d}^{-1}\right]$ using USGS daily discharge data for 12 stations in the Merrimack River Watershed with at least 17 years of data.

Nitrogen export ( $\left.W_{\text {Nitrogen }}\left[\mathrm{kg} \mathrm{N} y^{-1}\right]\right)$. Nitrogen export was selected as an indicator of the watershed regulation service of processing excess anthropogenic dissolved inorganic nitrogen (DIN) prior to export to sensitive estuarine habitats. $W_{\text {Nitrogen }}$ was calculated by subtracting an estimate of the annual estuary nitrogen loading that was determined to be protective of estuarine ecosystem function $\left(\dot{m}_{D I N}^{*}=350\left[\mathrm{~kg} \mathrm{~N} \mathrm{~km}^{-2} y^{-1}\right]\right.$, 
Trowbridge and NHDES 2010) from the total annual export of DIN predicted by PnETFrAMES.

\section{LITERATURES CITED}

Aber, J.D., and C.T. Driscoll. 1997. Effects of land use, climate variation, and N deposition on N cycling and C storage in northern hardwood forests. Global Biogeochemical. Cycles 11: 639-648. doi:10.1029/97GB01366

Alley, W., and J. Veenhuis. 1983. Effective Impervious Area in Urban Runoff Modeling. Journal of Hydraulic Engineering 109(2): 313-319

Dumont, E., J. A. Harrison, C. Kroeze, E. J. Bakker, and S. P. Seitzinger. 2005. Global distribution and sources of dissolved inorganic nitrogen export to the coastal zone: Results from a spatially explicit, global model, Global Biogeochemical Cycles 19:GB4S02, doi:10.1029/2005GB002488

Eaton, J.G., and R. M. Scheller. 1996. Effects of climate warming on fish thermal habitat in streams of the United States. Limnology and Oceanography 41(5): 1109-1115

Franks, P.J., M.A. Adams, J.S. Amthor, M. M. Barbour, J. A. Berry, D. S. Ellsworth, G.D. Farquhar, O. Ghannoum, J. Lloyd, N. McDowell, R. J. Norby, D. T. Tissue, and S. von Caemmerer. 2013. Sensitivity of plants to changing atmospheric CO2 concentration: from the geological past to the next century. New Phytol 197: 1077-1094. doi:10.1111/nph.12104

Fekete, B. M., C. J. Vörösmarty, and R. B. Lammers. 2001. Scaling gridded river networks for macroscale hydrology: Development, analysis, and control of error. Water Resources Research 37(7):1955-1967. 
Hayhoe, K., C. P. Wake, T. G. Huntington, L. Luo, M. D. Schwartz, J. Sheffield, E. Wood, B. Anderson, J. Bradbury, A. DeGaetano, T. J. Troy, and D. Wolfe. 2007. Past and future changes in climate and hydrological indicators in the US Northeast. Climate Dynamics 28: 381-407, DOI 10.1007/s00382-006-0187-8

Horn, M. A., R. B. Moore, L. Hayes, and S. M. Flanagan. 2008. Methods for and estimates of 2003 and projected water use in the Seacoast Region, southeastern New Hampshire: U.S. Geological Survey Scientific Investigations Report 20075157. Available at: http://pubs.usgs.gov/sir/2007/5157/.

Iverson, L. R., A. M. Prasad, S. N. Matthews, and M. Peters. 2008. Estimating potential habitat for 134 eastern US tree species under six climate scenarios. Forest Ecology and Management 254: 390-406

Lehner, B., K. Verdin, and A. Jarvis. 2008. New Global Hydrography Derived From Space borne Elevation Data. Eos, Transactions American Geophysical Union 89(10): 93-94.

Mavrommati, G., M. Borsuk, and R. B. Howarth. 2017. A novel deliberative multicriteria evaluation approach to ecosystem service valuation. Ecology and Society 22(2):39. https://doi.org/10.5751/ES-09105-220239

McCray, J.E., Kirkland, S.L., Siegrist, R.L., Thyne, G.D., 2005. Model Parameters for Simulating Fate and Transport of On-Site Wastewater Nutrients. Ground Water 43: 628-639. doi:10.1111/j.1745-6584.2005.0077.x

Miara, A. and C. J. Vorosmarty. 2013. A dynamic model to assess tradeoffs in power production and riverine ecosystem protection. Environemtnal Science - Processes and Impacts doi: 10.1039/C3EM00196B 
NOAA, NASA, and USAF. 1976. U.S. Standard Atmosphere, 1976. NOAA, Washington, D.C.

Ollinger, S.V., J.D. Aber, P.B. Reich, R.J. Freuder. 2002. Interactive effects of nitrogen deposition, tropospheric ozone, elevated $\mathrm{CO} 2$ and land use history on the carbon dynamics of northern hardwood forests. Global Change Biology 8: 545-562. doi:10.1046/j.1365-2486.2002.00482.x

Ollinger, S.V., C. L. Goodale, K. Hayhoe, and J. P. Jenkins. 2008. Potential effects of climate change and rising $\mathrm{CO} 2$ on ecosystem processes in northeastern U.S. forests, Mitigation and Adaptation Strategies for Global Change 13: 467-485, DOI 10.1007/s11027-007-9128-z

Olson, S.A. 2009. Estimation of flood discharges at selected recurrence intervals for streams in New Hampshire: U.S. Geological Survey Scientific Investigations Report 2008-5206:57

Pellerin, B. A., W. M. Wollheim, X. Feng, and C. J. Vörösmarty. 2008. The application of electrical conductivity as a tracer for hydrograph separation in urban catchments. Hydrological Processes 22(12):1810-1818

Price, A. 2014. Nitrate dynamics across temporal scales and land use types on three headwater catchments observed using high-frequency measurements. Masters thesis, 78, University of New Hampshire (Unpublished)

Shuster, W. D., J. Bonta , H. Thurston , E. Warnemuende, and D. R. Smith. 2005. Impacts of impervious surface on watershed hydrology: A review, Urban Water 2(4): 263-275, DOI: 10.1080/15730620500386529

Stewart, R.J., W.M. Wollheim, M.M. Mineau, S. Zuidema, K. Whittinghill, and B. 
Rosenzweig. In Prep. Natural vs. Anthropogenic Aquatic Infrastructure: How much do rivers contribute to wastewater nitrogen treatment in northeast U.S.?

Stewart, R. J., W. M. Wollheim, A. Miara, C. J. Vörösmarty, B. Fekete, R. B. Lammers, and B. Rosenzweig. 2013. Horizontal cooling towers: riverine ecosystem services and the fate of thermoelectric heat in the contemporary Northeast US.

Environmental Research Letters 8(2): 025010.

Stewart, R. J., W. M. Wollheim, M. N. Gooseff, M. A. Briggs, J. M. Jacobs, B. J.

Peterson, and C. S. Hopkinson. 2011. Separation of river network-scale nitrogen removal among the main channel and two transient storage compartments. Water Resources Research 47(1): W00J10, doi:10.1029/2010WR009896

Stoner, A. M. K., K. Hayhoe, X. Yang, and D. J. Wuebbles. 2013. An asynchronous regional regression model for statistical downscaling of daily climate variables. Climatology 33: 2473-2494, doi:10.1002/joc.3603

Tarboton, D.G., K.A.T. Schreuders, D.W. Watson, and M.E. Baker. 2009. Generalized terrain-based flow analysis of digital elevation models. 18th World IMACS / MODSIM Congress, Cairns, Australia 13-17 July 2009, http://mssanz.org.au/modsim09

Thorn, A.M., C.P. Wake, C. Grimm, C. Mitchell, M. Mineau, and S.V. Ollinger. Future scenarios of land cover in New Hampshire and implications for habitat, watersheds, urbanization and local food production. Ecology and Society. In this issue.

Trowbridge, P., and NHDES (2010), DRAFT Appendix B: Nitrogen Loading Thresholds for the Great Bay Estuary in Analysis of Nitrogen Loading Reductions for Wastewater Treatment Facilities and Non-Point Sources in the Great Bay Estuary 
Watershed, NHDES, Concord, NH. USEPA. 1998. National water quality inventory: 1996 Report to Congress. EPA-841-R-97-008, Office of Water, Washington D.C.

USEPA. 1988. Ambient Aquatic Life Water Quality Criteria for Chloride. EPA 440/5-88001

USEPA. 2008. Municipal nutrient removal technologies reference document: Vol. 1. Technical report. EPA-832-R-08-006, Office of Wastewater Management, Washington D.C.

Van Drecht, G., A. F. Bouwman, J. Harrison, and J. M. Knoop. 2009. Global nitrogen and phosphate in urban wastewater for the period 1970 to 2050 , Global Biogeochemical Cycles 23: GB0A03, doi:10.1029/2009GB003458

Vorosmarty, C. J., C. A. Federer, and A. L. Schloss. 1998. Evaporation functions compared on US watersheds: Possible implications for global-scale water balance and terrestrial ecosystem modeling. Hydrology 207: 147-169

Wake, C., E. Burakowski, P. Wilkinson, K. Hayhoe, A. Stoner, C. Keeley, and J. LaBranche. 2014. Climate Change in Southern New Hampshire Past, Present, and Future. Page 80. Climate Solutions New England, Durham NH

Wisser, D., B. M. Fekete, C. J. Vorosmarty, and A. H. Schumann. 2010. Reconstructing 20th century global hydrography: a contribution to the Global Terrestrial Network-Hydrology (GTN-H). Hydrology and Earth System Sciences 14: 1-24

Wollheim, W. M., C. J. Vorosmarty, A. F. Bouwman, P. A. Green, J. Harrison, E. Linder, 
B. J. Peterson, S. Seitzinger, and J. P. M. Syvitski. 2008a.Global N removal by freshwater aquatic systems: A spatially distributed, within-basin approach. Global Biogeochemical Cycle 22: GB2026, doi:10.1029/2007GB002963

Wollheim, W. M., B. J. Peterson, C. J. Vorosmarty, C. Hopkinson, and S. A. Thomas. 2008b. Dynamics of N removal over annual time scales in a suburban river network Geophysical Research 113: G03038, doi:10.1029/2007JG000660

Wollheim, W.M., M. B. Green, B. A. Pellerin, N. B. Morse and C. S. Hopkinson. 2015. Causes and consequences of ecosystem service regionalization in a coastal suburban watershed. Estuaries and Coasts 38: 19-34

Wythers, K.R., Reich, P.B., Bradford, J.B., 2013. Incorporating temperature-sensitive Q10 and foliar respiration acclimation algorithms modifies modeled ecosystem responses to global change. J. Geophysical Research Biogeoscience. 118: 77-90. doi:10.1029/2011JG001897

Xian, G., C. Homer, J. Dewitz, J. Fry, N. Hossain, and J. Wickham. 2011. The change of impervious surface area between 2001 and 2006 in the conterminous United States. Photogrammetric Engineering and Remote Sensing 77(8): 758-762

Yanai, R.D., M. A. Vadeboncoeur, S. P. Hamburg, M. A. Arthur, C. B. Fuss, P. M. Groffman, T. G. Siccama, and C. T. Driscoll. 2013. From Missing Source to Missing Sink: Long-Term Changes in the Nitrogen Budget of a Northern Hardwood Forest. Environ. Sci. Technol. 47: 11440-11448. doi:10.1021/es4025723

Zhou, Z., S.V. Ollinger, S. Glidden, W. Wollheim. In Prep. Regional effects of climate 
and land use on forest ecosystem processes at three watersheds in northeastern U.S.

Zuidema, S., W. M. Wollheim, M. M. Mineau, M. B. Green, and R. J. Stewart. In Prep. Macro-scale simulations of chloride loading and impairment in a New England river network. In prep for Journal of Environmental Quality. 
Figs. A4.1 - A4.4.

Fig. A4.1. Comparison of mean daily (annual only) modeled values with observations for a) streamflow (mm/d), b) water temperature (degC), c) DIN (mg/L) and d) specific conductivity (uS/cm)

( forested sites lovotecs oyster aquatic network)
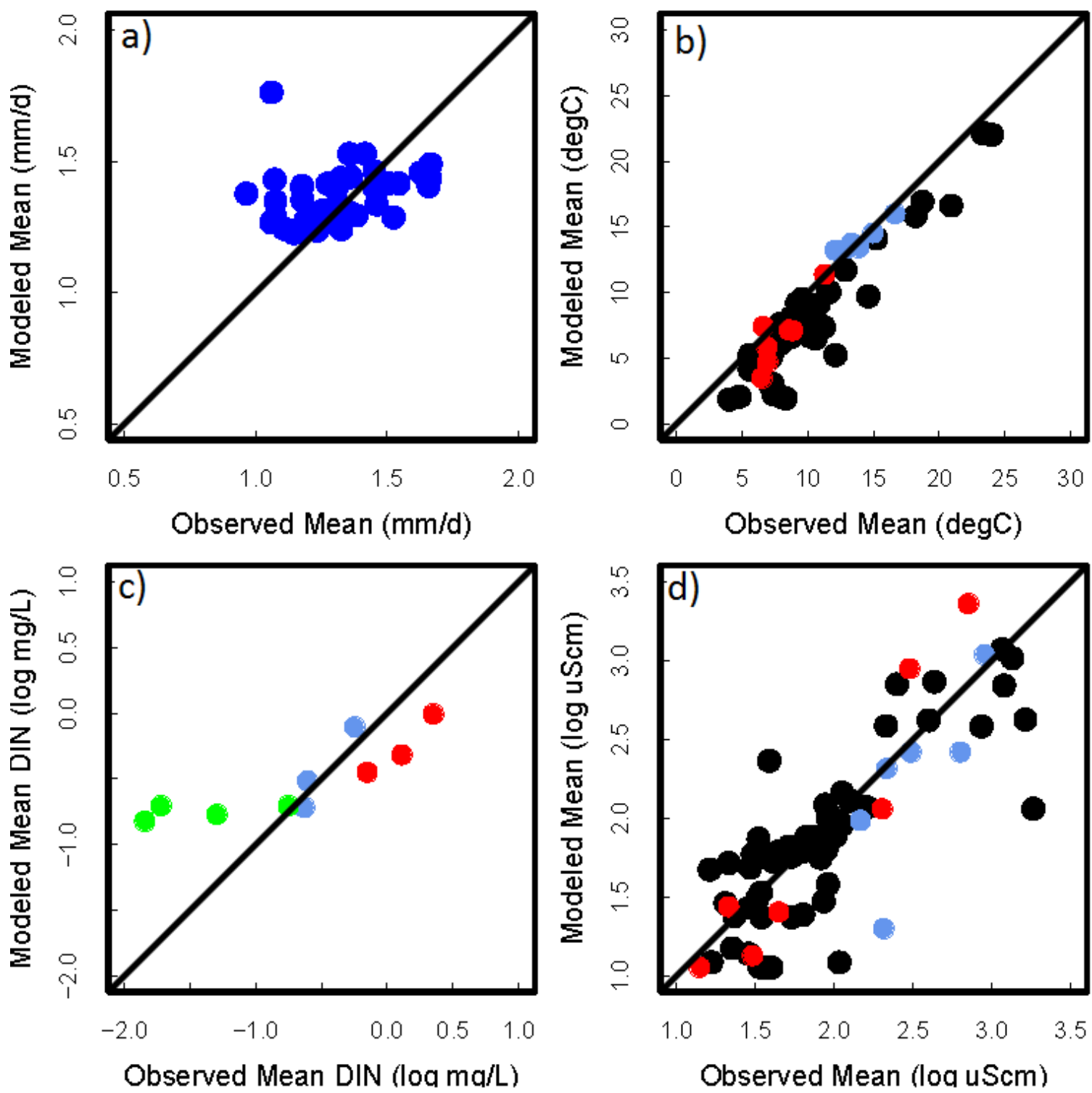
Fig. A4.2. Comparison of mean daily (summer only) modeled values with observations for a) streamflow $(\mathrm{mm} / \mathrm{d})$, b) water temperature $(\mathrm{degC}), \mathrm{c}) \mathrm{DIN}(\mathrm{mg} / \mathrm{L})$ and d) specific conductivity (uS/cm)

( forested sites lovotecs oyster aquatic network)
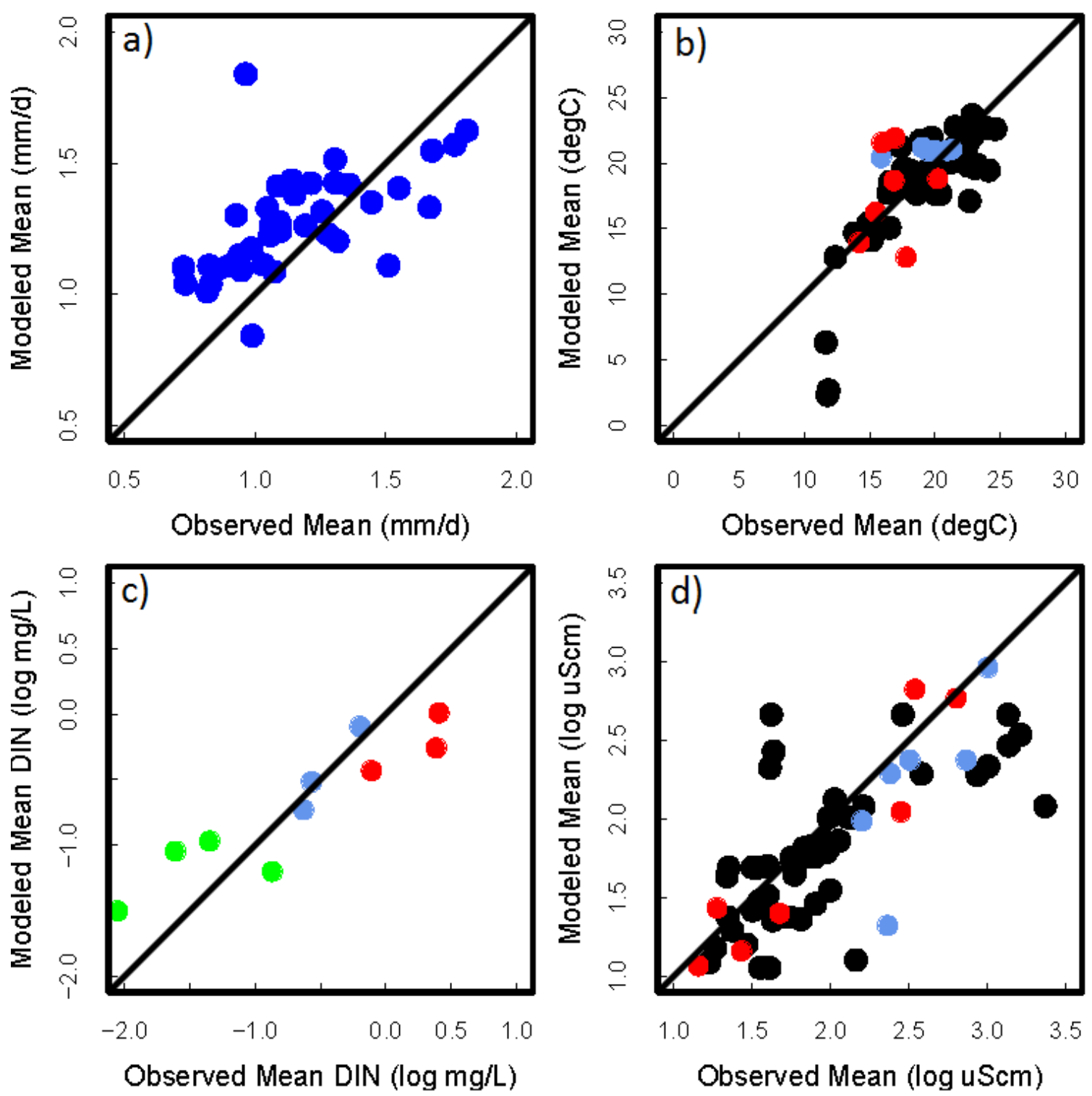
Fig. A4.3. Basin profiles (i.e. the longest flow path distance from the basin mouth to headwaters) for (a) DIN (mg/L), (b) river water temperature (deg C) and (c) specific conductivity $(\mathrm{uS} / \mathrm{cm})$ during mean summer conditions. The black and red lines represent coupled model results for the Merrimack and Piscataqua Rivers, respectively. Blue points show the mean and standard deviations for observations at LoVoTECS sites. The dotted line represents conservative mixing of DIN in a simulation without instream denitrification (Fig. A4.3a)
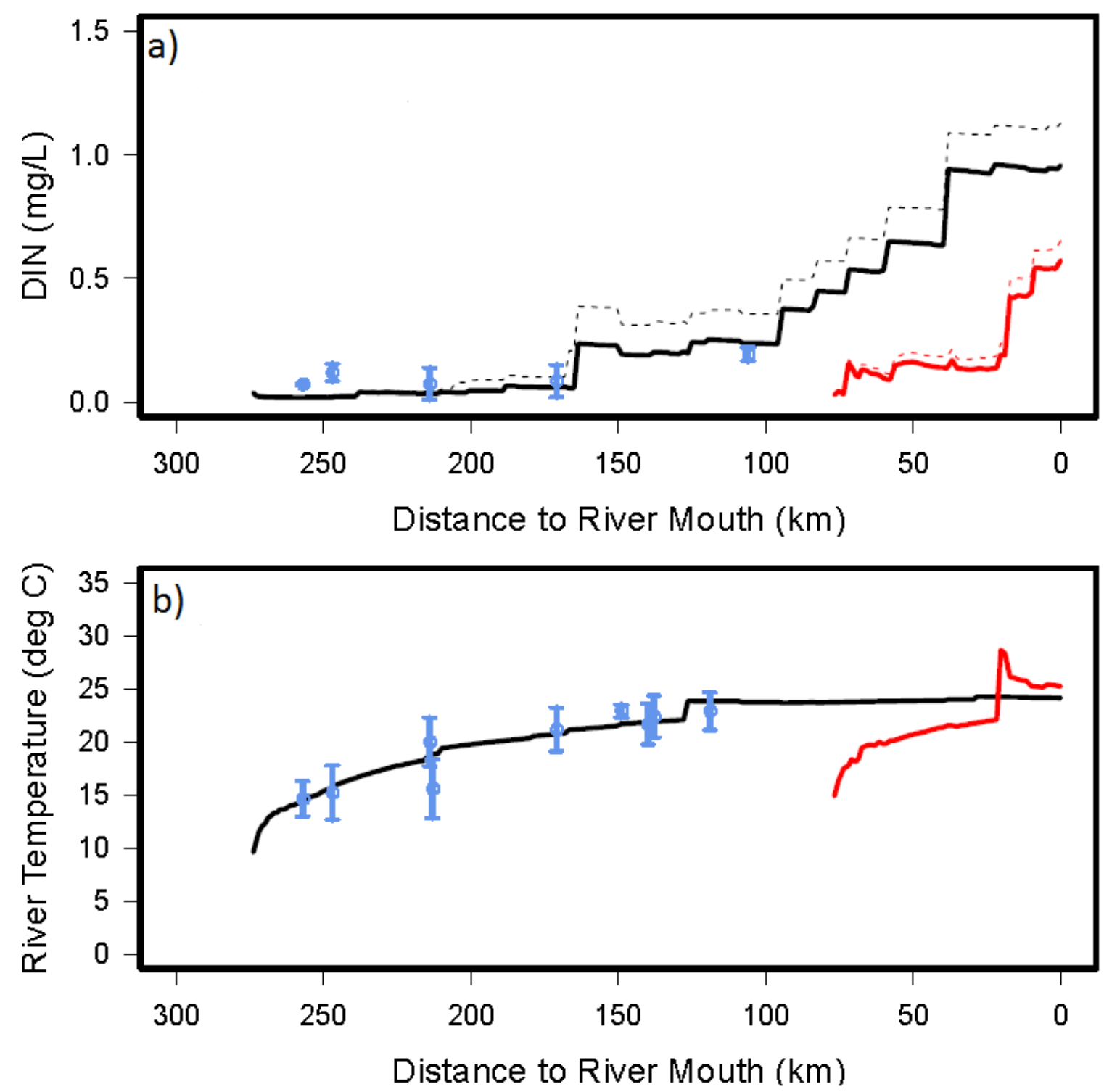


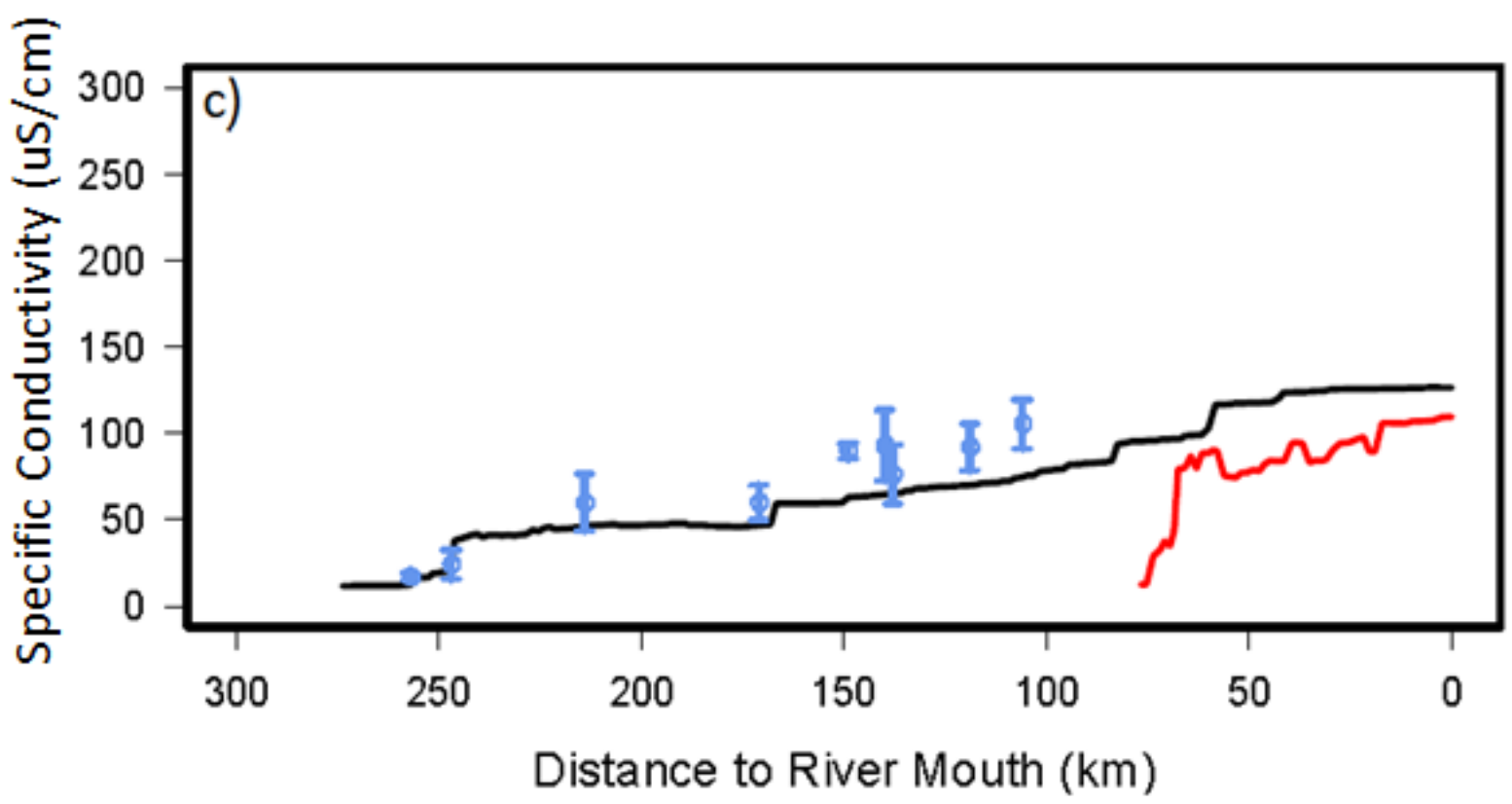


Fig. A4.4. Distribution of forest nitrogen load, summer water temperature and precipitation: a) Forest Nitrogen Load (kg/yr), b) Headwater Temperature Impaired (km d), c) Annual Precipitation (mm/yr), d) Summer Precipitation ( $\mathrm{mm} / \mathrm{yr}$ ), and e) Carbon

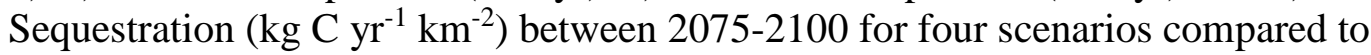
contemporary range (1980-2005). (a-e) Boxes represent first to third quartiles of data with line defining median, whiskers extend to $1.5 \times \mathrm{IQR}$, outliers as circles beyond.
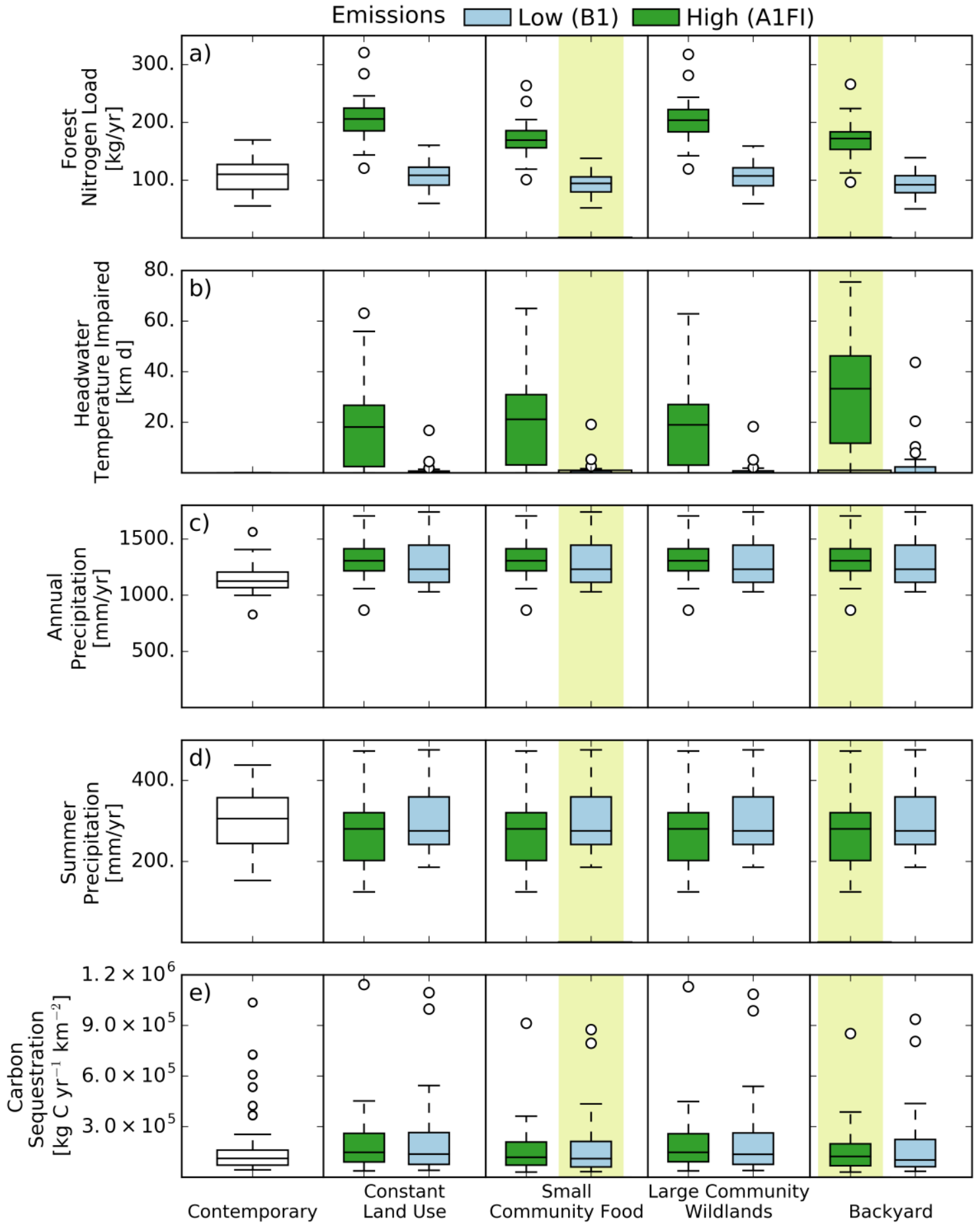